\title{
胎览皮膚の分裂線と皮下脂肪層との関係について
}

九州歯科大学解剖学教室 (指導 : 中山種秋教授)

$$
\text { 三 浦 敦 彦 }
$$

昭和52年 2 月 1 日受付

（本論文の要旨は昭和51年11月第32回日本解剖学会九州地方会において発表した）

\section{On the Relationship between the Splitting Lines of Embryonic Skin and the Fat Tissue Layer}

\author{
By \\ Atsuhiko Miura \\ Department of Anatomy (Director: Prof. Taneaki Nakayama) \\ Kyushu Dental College, Kitakyushu, Japan
}

Abe (1959) of this laboratory stated that the direction of the splitting lines approximately coincide with that of the hair stream in his study of the relation between the splitting lines and hair stream of embryonic skin, and pointed out that the splitting lines are conditioned by the running direction of the fiber fascicle at the superficial layer of corium, and at the same time the hair stream is conditioned by the direction of fiber fascicle at the border between the corium and the subcutaneous tissue, where the hair bulbus are placed.

However, no work has been reported on the relationship between the splitting lines of skin and the growth direction of the fat tissue layer. The author presumed, in view of the fact that the fat tissue is one of the components of the skin, though positioned at the deepest layer, that the growth direction of the fat tissue layer would coincide with the splitting lines direction, if the line system of the splitting lines is the manifestation of the growth direction. For this purpose, observations were made on the relations of the splitting lines and growth direction of the fat tissue layer in the trunk where the growth of fat tissue layer is notably seen in the human embryo, examining 15 samples altogether, or 3 samples each of the breast, upper and middle abdomen, lower abdomen, back and gluteus.

Usual observation and experiment were made to the splitting lines of the skin, but special attention was paid to do not hurt the subcutaneous tissue in peeling off the skin to expose the fat tissue layer. In the observation of the fat tissue layer, the configurations, size and positional arrangements of the fat granules were observed in detail through the magnifier. Following conclusions have been obtained by these observations: 
1. The conditions of splitting lines of skin and those of the fat tissue layer are, although slighty different in the umbilicus region, generally in well aligned mutual relationship. In the fat tissue layers of the areas, corresponding to the independent line systems of the splitting lines, fat granules of ellipsoidal shape and of respectively different sizes are arranged, and as their length diameter leads to an uniform direction, indicates the obvious growth direction of the fat tissue layer. This direction conforms well to the direction of the line systems of the splitting lines.

2. Some areas surrounded with 2-3 independent line system groups are filled with irregular splitting line groups. The fat tissue layer corresponding to such area is collecting small fat granules of cuboidal shape and does not indicate any direction.

3. Above observations evidently prove prof. Nakayama's view that "the line system is the manifestation of the growth direction and the irregular splitting lines show the disturbance of the growth direction", or in other words "the splitting lines are the growth architecture."

\section{緒言}

皮庵の分裂線に関しては，Dupuytren (1836) ${ }^{12}$ ， を 始めとし Langer $(1861)^{2)}$, Burkard $(1913)^{3)}$, 小木 層 $(1942)^{4)}$, 友田 $(1949)^{5)}$, 山本 $(1950)^{6)}$, 連理 $(1951)^{7)}$, 西尾 $(1951)^{8)}$ ，橋本 $(1954)^{91}$ ， らの報告 をみることができる。しかしながら，てれらの業績は， 線維構築の状況を，単に分裂線法によって明らかにした のみであり，しかも線系のみを観察し，不整裂線の存 在とその意義を全く認めていないのである.しかし中 山 $(1957)^{10}{ }^{\prime}$ は骨分裂線に関する研究を総合して, 特に 不整裂線の存在とその意義を強調し, 線系は発育方向の 示現であり, 不整裂線は内的発育力の衝突あるいは外力 的影響に基づく発育方向の乱れであって，骨質自身の示 す防禦反応的直接の機能表現であるとしている，以来， 我が教室では, 軟組織に関してもこの見解が成りたつか 否かを検討してきたものであり，土佐（1956）11， 大森 $(1957)^{12)}$ ，阿部 $(1959)^{13)}$, 鶴丸（1959） 14)，(1960) ${ }^{15)}$, 松幔 $(1960)^{16)}$, 沖重 $(1960)^{17}$, 中道 $(1969)^{1{ }^{12}}$, 森 $(1971)^{191}$ ，小川 $(1976)^{201}$ ，村上 $(1976)^{21}$ ) によ り，骨の場合におけると全く同様に，中山の見解がその まま成立することを実証している，な抬坚皮膚の分裂

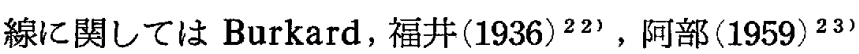
らの報告があり，また人胎児の皮下脂肪層に関しては， Oeder $(1911)^{24)}$, Neuman $(1922)^{25)}$, Batkin (19 $15)^{26)}$, Peisen $(1921)^{271}$, Lasch $(1927)^{28)}$, Baüer $(1922)^{29}$, Hille $(1923)^{30}$, 徳永 $(1956)^{31}$, 最勝 寺 $(1958)^{32)}$, 柴山 $(1960)^{331}$, 橋本 $(1958)^{34}$, 浅井

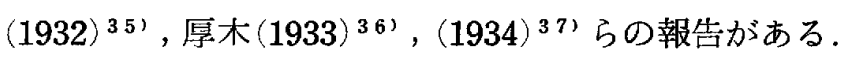
しかしながら胎児の皮膚分裂線と皮下脂肪層との関係に ついてはなんら報告をみることができない，また胎児皮 膚の分裂線と毛流との関係について1959年阿部は皮膚分 裂線と毛流との走行はほぼ一致するとしている。すなわ ち分裂線が真皮表層に打ける線維束の走行によって規定 され，一方毛流が毛球を乗せている真皮と皮下組織との 境界層に扔ける線維束の走行に規定されていることを指 摘している，そこで著者は皮下脂肪風が皮膚の最深層で はあるが, 皮唐構成組織であるととから, 分裂線の線系 が発育方向の示現であるならば, 脂肪圆の発育方向もほ ぼ一致した走行を示すのではないか，層的違いが皮膚表 層と脂肪層表面との間にどの程度の差異を示すかを知る ため, 脂肪層発育の顕著な体幹部について，人胎児を用 いて, 皮膚分裂線と皮下脂肪層とを詳細観察し, 興味 ある所見を得たので報告する。

\section{実験材料ならびに方法}

研究材料は九州䨑科大学解剖学教室所蔵の人胎児で, $10 \%$ ホルモール中に保存したもので, 胸部 3 例，上腹部 -中腹部 3 例, 下腹部 3 例, 背部 3 例および殿部 3 例 の計15例である. 実験方法は, 先ず胎児皮膚に通法の如 く墨汁穿刺し，写真撮影を行ない，陽画を作製した。乙 の陽画と契物とを照合しながら正確にスケッチを行なっ た。つぎに，皮剝に祭しては皮下脂肪層を傷つけない上 うに細心の注意を払いながら脂肪囷を表出した。また脂 肪層における柾性結合組織の網眼中にみられる脂肪顆粒 の形態は脂肪摄取の状態に伴って変化すると同時に線維 
束の主方向を決定づけるはずであるから，乙のととより 脂肪顆粒の形態と大きさを注意深く観察した。ただし本 研究では，皮下脂肪の分布状沅が良好である体幹（胸 部，上腹部・中腹部，下腹部，背部，殿部）のみの観察 に止めた．脂肪顆粒の大きさが肉眼的にみて点状のも の，および直径が 0.5mm以内のものを小型， $1 \mathrm{~mm}$ 内のものを中型, $1 \mathrm{~mm}$ 以上のものを大型とし, 脂肪顆粒 の形態を円形，楕円形，不定形の 3 種類に分けた。しか し脂肪顆粒の分布密度に関しては特に基準はもうけなか
った.

所見

所見の記述にあたって，胎児は未だ発育が不十分なた め，身体各部境界の不明瞭な場合が多いので，成人のそ れに準じて区分した。

\section{A. 胸 部}

胸部における分裂線および皮下脂肪層の状況は図 1 亿 示すごとくである。観察の便宜上，前頸部，側頸部，肩

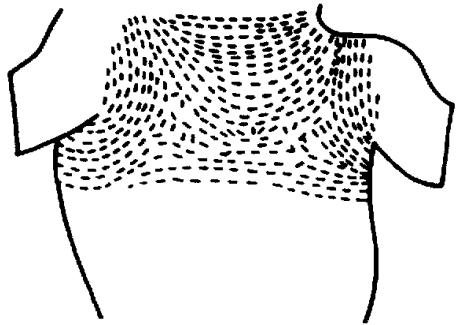

写生図

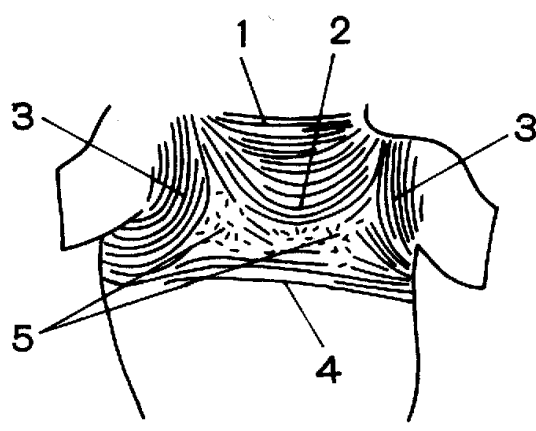

模 式 図

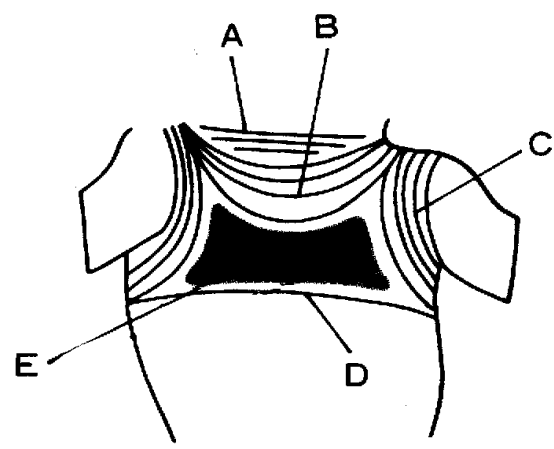

脂肪風の走行

胸 部例 1 胎児 6 少月

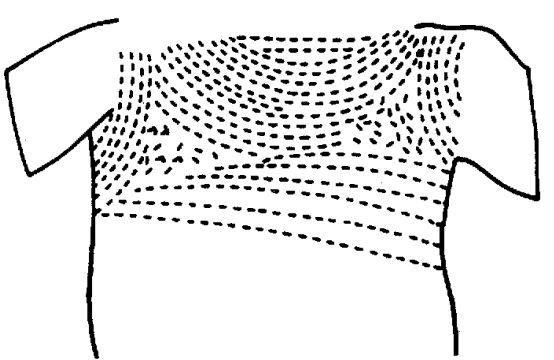

写生 図

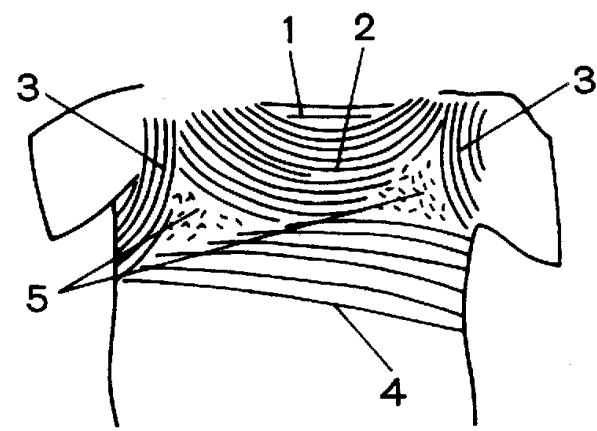

模 式 図

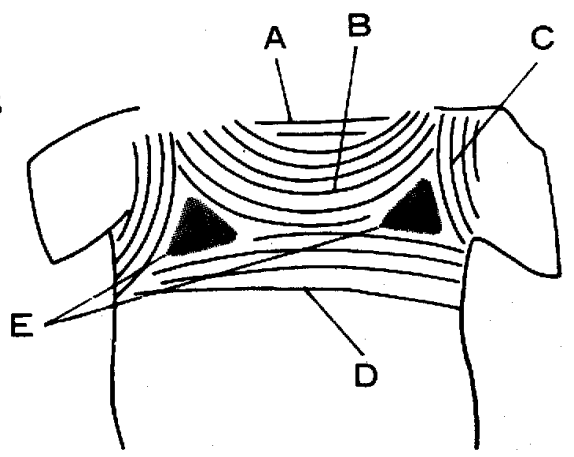

脂肪層の走行

胸部例 2 胎耐 8 汃月

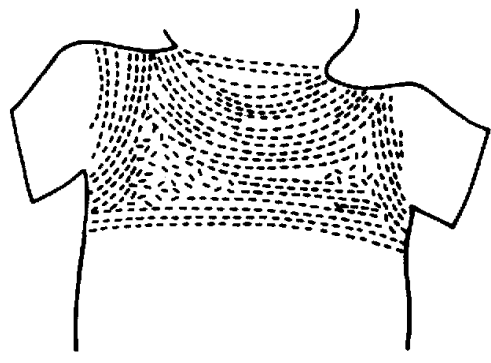

写生図

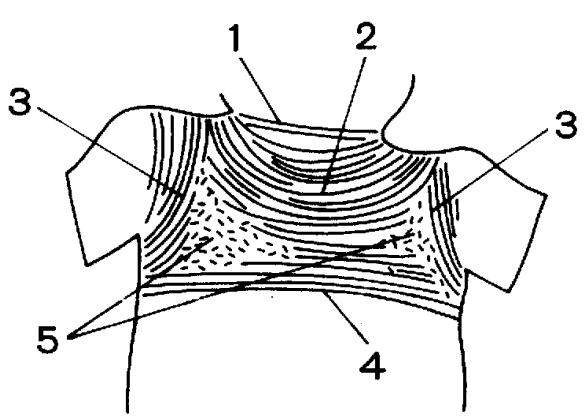

模 式図

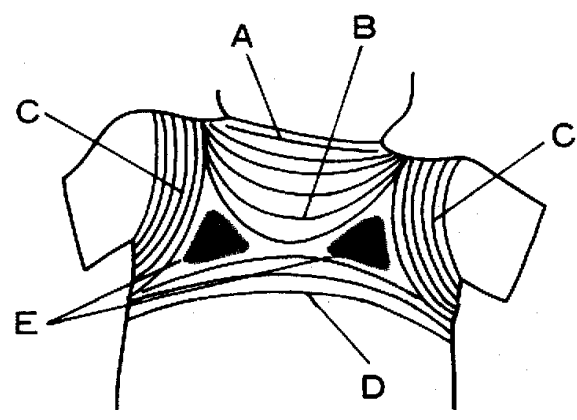

脂肪層の走行

胸 部例 3 胎坚 10 か 月 
峰部を胸部に含めて記載した。

例 1 胎児 6 汃月（早）

a. 分裂線の状況

前頸部抢よび左右側頸部領域には横走線系群 (1) が みられ，乙の横走線系群（1）の下方の領域，すなわち 前胸部の胸骨柄部，鎖骨部，鎖骨下部には，左右の肩峰 の内側部を連らね，下方に凸をなす弧状線系群（2）が 認められる．また左右の肩峰の内側部および鑜骨上部の 領域から同側の腋窩部に向って，内方に凸をなす弧状線 系群（3）が虫められ, 左右の側胸部および下肋部と上 胃部，すなわち上腹部の全面には横走線系群（4）が認 められる，前胸部の弧状線系群 $(2)$, 左右の鎖骨部お了 よび腋窝部の弧状線系群（3）, 左右の 側胸部扔よび上 腹部の横走線系群（4）によって囲まれた領域，すなわ ち将来乳房を形成する部は不整裂線団（5）に充たされ ている。

\section{b . 皮下脂肪凮の状況}

前頸部では，小型のやや円形に近い楕円形を主体とし た脂肪顆粒からなり，顆粒はその長径を一定方向に向け て排列し，頸部をとり巻くように並んでいる（A)．前 胸部の胸骨柄部，鎖骨部，鎖骨下部では，小型のやや円 形に近い棈円形を主体とした脂肪顆粒からなり顆粒はそ の長径を一定方向に向けて排列し, 左右の肩峰の内側部 を連らね，下方に凸をなすように並んでいる（B）。左 右の肩峰の内側部, 鎖骨上部, 乳房部の外上方部, なら びに腋窩部では小型の円形に近い棈円形を主体とした脂 肪顆粒からなり，顆粒はその長径を一定方向に向けて排 列し，左右の肩峰内側部之同側の腋窝部を結ぶように並 んでいる（C）。左右の側胸部および上腹部では，中型 の楕円形を主体とした脂肪顆粒からなり，顆粒はその長 径を一定方向に向けて排列し，体幹を取り巻くように並 んでいる(D). 左右の将来乳房を形成する部では，小 型の円形を主体とした脂肪顆粒からなり，顆粒は円形で あるためにその方向性はみられない（E）。

c ．胸部の皮膚分裂線と皮下脂肪層との比較

前頸部では，横走線系群（1）の走向とこれに対応す る脂肪層 (A) の脂肪顆粒の排列方向とは一致してい る．前胸部の胸骨柄部，鎖骨部，鎖骨下部では，弧状線 系群 (2) の走向と乙れに対応する脂肪層 (B) の脂肪顆 粒の排列方向とは一致している. 左右の肩峰の内側部,

鎖骨上部，乳房部の外上方部，ならびに腋窩部では弧状 線系群（3）の走向とこれに対応する脂肪層（C）の脂 肪顆粒の排列方向とは一致する．左右の側胸部および上 腹では横走線系群（4）の線系方向とこれに対応する脂
肪層（D）の脂肪顆粒の排列方向とは一致する．将来乳 房を形成する部では，不整裂線団（5）に充たされてお り，てれに対応する部の脂肪層（E）の脂肪顆粒は小型 円形であり方向性はみられない，ただ小型円形で方向性 のみられない脂肪首 (E) の顆粒の 範囲は 不整裂線団

(5)の範囲よりやや広い。

例2. 胎览 8 力月（早）

a. 分裂線の状況

前頚部および左右の 側頸部の 領 域には 横走 線 系 群 （1），前胸部の胸骨柄部，鎖骨部，鎖骨下部には弧状 線系群（2）左右の肩峰内側部, 鎖骨上部, 腋窩部には 弧状線系群（3），左右の側胸部抢上び下肋部，上胃部 には横走線系群（4）が認められる. 弧状線系群 (2), (3)，扔よび横走線系群（4）に囲まれる領域の不整裂 線団（5）は左右の中間部が線系化しており, 左右乳房 部に分かたれて諗められる。

b . 皮下脂肪層の状況

前頸部には脂肪層 (A)，胸骨柄部，鎖骨部，鎖骨下 部には脂肪層（B），左右の鎖骨部および腋窩部には脂 肪層（C）が認められ，いずれも小型の楕円形を主体と した脂肪顆粒からなり，顆粒はその長径を一定方向に向 けて排列している．左右の側胸部抢よび下肋部，上胃部 には脂肪層 (D) が認められ, 中型の棈円形を主体とし た脂肪顆粒からなり，顆粒はその長径を一定方向に向け て排列している，また左右の 将来乳房を形成する部で は，小型の円形を主体とした脂肪顆粒からなり，顆粒は 円形であるためにその方向性はみられない（E）。

\section{c . 胸部の皮膚分裂線と皮下脂肪首との比較}

前頸部および左右の側頸部には 横走線系群 (1), 胸 骨柄部，鎖骨部，鎖骨下部には弧状線系群 (2), 左右 の鎖骨部および腋窝部には弧状線系群（3）, 左右の側 胸部抢よび下肋部, 上胃部には横走線系群 (4) が認め られ, 以上の各線系群の走向とてれに対応する部の脂肪 層 (A)，(B)，(C)，(D) の脂肪顆粒の排列方向とは 一致する．左右の将来乳房 を形成する 部は不 整裂線団 （5）に充たされ，乙れに対応する部の脂肪層（E）の脂 肪顆粒は小型円形であり方向性はみられない.

例3，胎児10加月（早）

a . 分裂線の状況

前頸部および 左右の 側 頸 部の 領域には 横 走 線系群 (1), 前胸部には弧状線系群（2）, 左右の䥊骨部およ び腋窩部には弧状線系群 (3), 左右の側胸部および下 肋部, 上胃部には横走線系群 (4) が認められる. 将来 
乳房を形成する部の不整裂線団（5）は，左右の中間部 が線系化し，左右の乳房部に分かたれて誌められる.

b . 皮下脂肪風の状況

前頸部には脂肪風 $(\mathrm{A})$ ，胸骨柄部，鎖骨部，鎖骨下 部には脂肪層（B），左右の鎖骨部および腋䆚部には脂 肪層（C）が認められいずれも小型の楕円形を主体とし た脂肪顆粒からなり，顆粒はその長径を一定方向に向け て排列している．左右の側胸部および下肋部，上胃部に は脂肪層（D）が認められ，やや大型の棈山形を主体と した脂肪顆粒よりなり顆粒はその長径を一定方向に向け て排列している。 また左右の将来乳房を形成する部で は，小型の円形を主体とした脂肪顆粒からなり，脂肪顆 粒は円形であるためにその方向性はみられない（E）。

c 、胸部の皮膚分裂線と皮下脂肪層との比較

前頸部および左右の 側頸部の横走線系群 (1), 前胸 部の弧状線系群（2），左右の鎖骨部および腋䆚部の弧 状線系群 (3), , 左右の側胸部, および下肋部, 上胃部 の横走線系群（4）などの走向とこれに対応する部の脂 肪層 (A)，(B)，(C)，(D) の脂肪顆粒の排列方向と は一致し，不整裂線団（5）が認められる部，すなわち 将来乳房を形成する部に対応する脂肪層（E）は，脂肪 顆粒が小型の円形であるために，その方向性はみられな い.

\section{胸部小括}

例 1 , 例 2 ，例 3 ともに前頚部および左右の側頸部の 横走線系群（1），前胸部の弧状線系群（2），左右の鎖 骨部および腋窝部の 弧状線系群 (3), 左右の側胸部, 下肋部，上胃部の横走線系群（4）などの線系が認めら れ，独立的な各線系群に対応する部の皮下脂肪風 (A)， （B），（C），（D）はそれぞれ異なった大きさの棈円形 を主体とした脂肪顆粒が排列しており，その長径が一定 した方向を示すため顆粒の排列方向は明瞭であり脂肪層 の走行と 各線系群の 分裂線の走向とはよく一致してい る. また, 弧状線系群 (2)，(3)，横走線系群 (4) に囲まれる部には，不整裂線団（5）が認められ，乙の

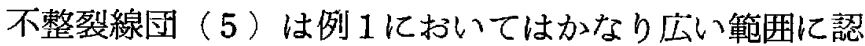
められるが，例 2 ，例 3 の 2 例においては左右に分かた れて琹められる。乙れに対応する部の脂肪層（E）は例 1 においてはかなり広い範囲に認められ, 例 2 , 例 3 の 2 例に扔いては多少の差異はあるが，左右に分かたれて 認められる．乙の脂肪層（E）の脂肪顆粒は小型の円形 であるために，その方向性は涊められない。

B ．上腹部および中腹部

上腹部および中腹部における分裂線の状沉および皮下
脂肪層の状沉は図 2 に示すでとくである。

例1. 胎览 6 加月（早）

a . 分裂線の状況

上腹部および中腹部の上方領域では，胸部でもみられ た横走線系群（4），が著明に認められる，臍周縁部で は，胎をとり巻く囲繞線系化の傾向を示す不整裂線団 （6）がみられる．中腹部の中央領域では横走線系群 4) は臍周縁部の不整裂線団（6）により分断されてい る. 中腹部の下方領域には左右の側腹部を連らね, 下方 に凸をなす弧状線系群（7）が琹められる。

\section{b . 皮下脂肪層の状況}

上腹部では中型の楕円形を主体とした脂肪顆粒からな り，顆粒はその長径を一定方向に向けて排列し，左右の 体幹をとり巻くょうに並んでいる（D），臍周縁部では 中型，楕円形の脂肪顆粒が胎をとりまくように排列して いるのが認められ，その上下の部はそれぞれ上・下方に 凸をなすように排列している（F）。中腹部下方領域で は: 中型の棈円形をした脂肜顆粒からなり，顆粒はその 長径を一定方向に向けて排列し，左右の側腹部を連らね 下方に凸をなすように並んでいる（G）。

c 、上腹部および中腹部の皮膚分裂線と皮下脂肪層 との比較

上腹部および 中腹部の 上方領域では，横 走線 系 群 （4）がみられとの走向とてれに対応する部の脂肪風

(D) の脂肪顆粒の排列方向とは一致する．臍周縁部で は囲繞線系化の 傾向を 示す 不整裂線団 (6) が認めら れ，乙れに対応する脂肪層（F）の脂肪顆粒は明らかに 臍をとり巻くように並んでいる，中腹部の下方領域では , 弧状線系群（7）がみられ，乙の走向とてれに対応す る部の脂肪層（G）の脂肪顆粒の 排列方向とは一致す る.

例2. 胎児 8 分月（早）

a . 分裂線の状況

腹部および中腹部の上方領域では，胸部でもみられる 横走線系群 (4), 臍部中央では国繞 線系化の傾向を示 す不整裂線団 (6), 中腹部の下方領域では弧状線系群

(7) が認められる.

b ． 皮下脂肪層の状況

上腹部では脂肪䊩（D）が認められ，左右の体幹をと りまくように中型の棈円形を主体とした脂肪顆粒が骎径 を一定方向に向けて排列している．また臍周縁部では中 型の楕円形の脂肪顆粒が臍をとりまくように排列してい るのが認められる．その上下の部はそれぞれ上・下方に 凸をなすように配列している（F）：中腹部下方の領域 


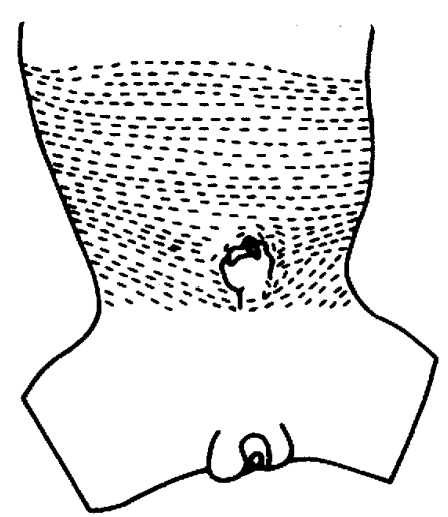

写 生 図

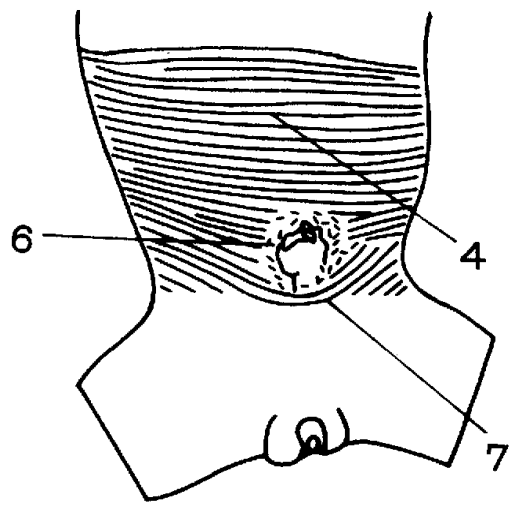

模 式図

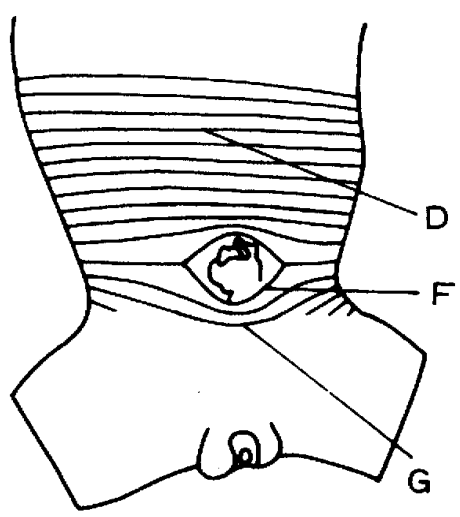

脂肪層の走行

上腹部抢よび中腹部 例 1 胎 児 6 か 月

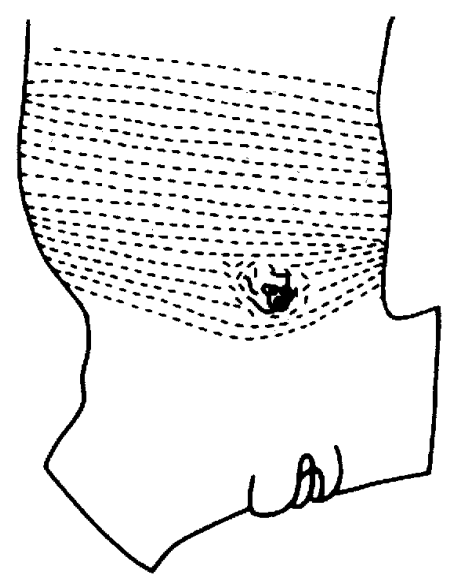

写 生 図

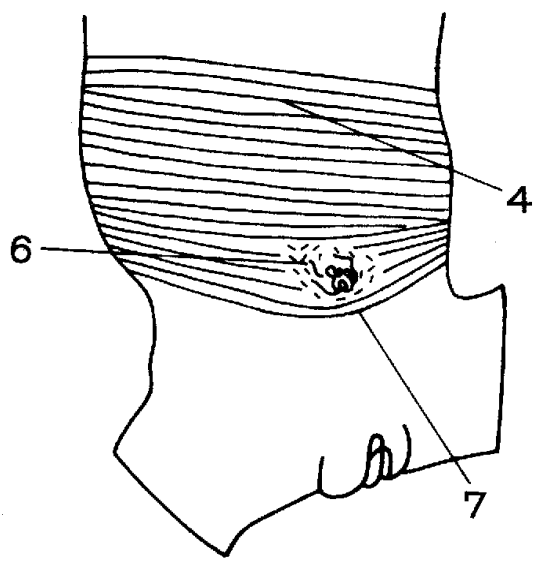

模 式 図

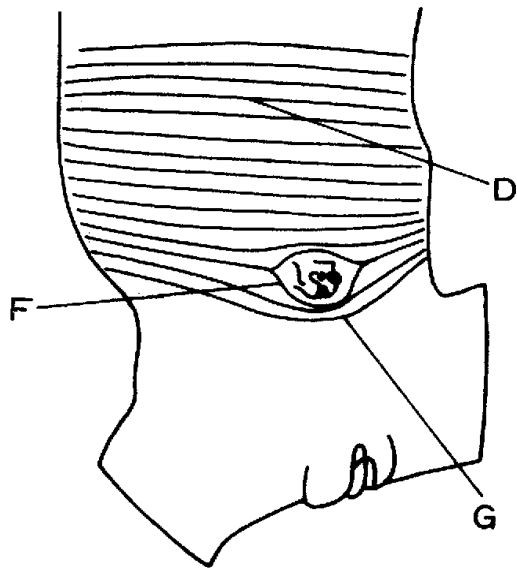

脂肪層の走行

上腹部および中腹部 例 2 胎 児 8 か 月

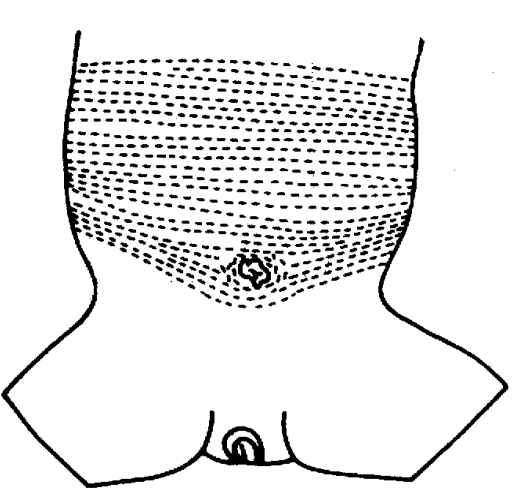

写 生 図

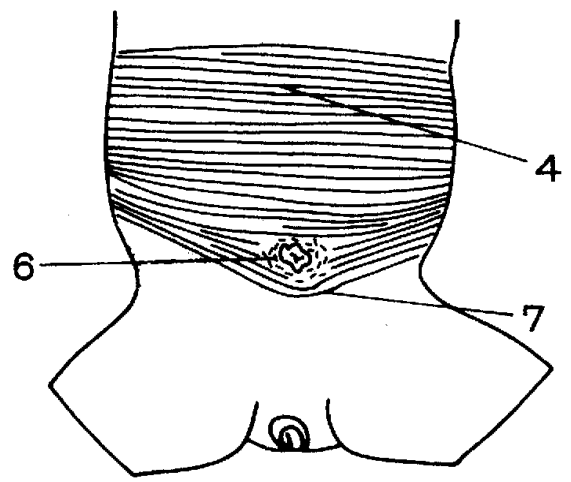

模式図

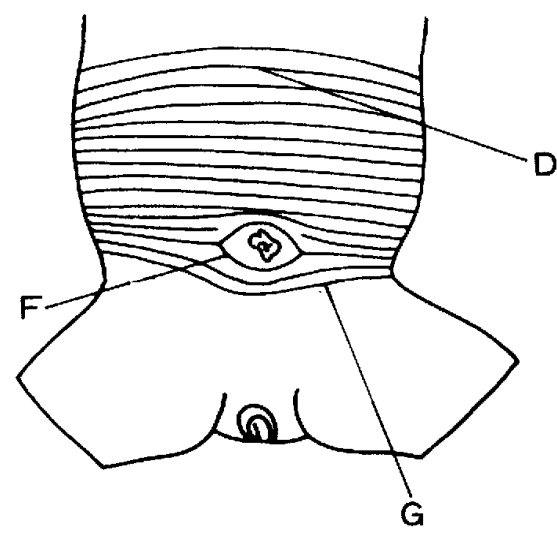

脂肪層の走行

上腹部および中腹部 例 3 胎 巟 10 か 月 
では，中型の楕円形の脂肪顆粒からなり，顆粒はその長 径を一定方向に向けて排列し，左右の側腹部を連らね下 方に凸をなすように並んでいる（G）。ただし側腹部の 脂肪顆粒は例 1 よりやや小型である．しかしながら例 1 に比べ全体的に脂肪顆粒の密度は高く認められる。

c .上腹部および中腹部の皮膚分裂線と皮下脂肪首 との比較

上腹部および中腹部の上方領域では，胸部でもみられ る横走線系群 (4), 中腹部の下方領域には左右の側腹 部を連らね下方に山をなす弧状線系群（7）などの走向 とこれに対応する脂肪層 (D)，（G）の脂肪顆粒の排列 方向とは一致し，团綥線系化の 傾 向を示す不整裂線団

（6）に対応する部の脂肪風（F）では脂肪顆粒は，明 らか臍をとり巻くように排列している。

例3. 胎児10か月（古）

a. 分裂線の状況

上腹部および中腹部の上方 領 域では，横 走 線系群 (4)，臍部中央では团繞線系化の傾向を 示す不整裂線 団 (6)，中腹 部の下方領域では 左右の側腹 部を 連ら ね，下方に凸をなす弧状線系群（7）が認められる.

\section{b ， 皮下脂肪層の状況}

上腹部では中型の楕円形を主体とした脂肪顆粒からな り，顆粒はその長径を一定方向に向けて排列し，左右の 体幹をとり巻くょうに並んでいる（D）。臍周縁部では 中型の棈円形の脂肪顆粒が臍をとりまくように排列して いるのが認められ，その上下の部はそれぞれ上・下方に 凸をなすように配列している（F)，中腹部下方領域で は，中型の楕円形をした脂肪顆粒からなり，顆粒はその 長径を一定方向に向けて排列し，左右の側腹部を連らね 下方に山をなすように並んでいる（G）。しかし例 1 ， 例 2 に比へ脂肪顆粒は全体的にやや大きくなり，その密 度も高くなる。

c . 上腹部おるよび中腹部の皮膚分裂線と皮下脂肪層 との比較

上腹部および中腹部の上方領域に認められる横走線系 群 (4)，中腹部の下方領域に認められ 左右の側腹部を 連ら和下方に凸をなす弧状線系群（7）などの走向とこ れに対応する脂肪層（D），(G）の脂肪顆粒の排列方向 とは一致し，团繞線系化の傾向を示す不整裂線団（6） に対応する部の脂肪層（F）では脂肪顆粒は，明らかに 蟀をとり巻くように排列している。

\section{上腹部および中腹部小括}

例 1 , 例 2 , 例 3 と与に上腹部の横走線系群 (4), 中腹部下方領域でみる 弧状線系群（7），などの線系が
認められ，独立的な各線系群に対応する部の皮下脂肪首

（D），(G）は，それぞれ異なった大きさの棈円形をし た脂肪顆粒が排列しており，その長径が一定した方向を 示すため, 顆粒の排列方向は明瞭であり脂肪層の走行と 各線系群の分裂線の走向とは，上く一致している．臍周 縁部には不整裂線団（6）が認められ，てれに対応する 部の脂肪層（F）は中型の楕円形の脂肪顆粒よりなり， 臍をとり巻くようであり，臍の上・下方に凸をなすよう に排列している。

\section{C. 下腹 部}

下腹部における分裂線の状況抢よび皮下脂肪層の状況 は図 3 に示すでとくである.

例1. 胎览 6 加月（早）

\section{a . 分裂線の状沉}

左右の鼠径部では上前晹骨棘部より恥骨結節外側部に 向い下方はほぼ斜走であるが漸次，上内方に向って突出 度を増して行く弧状線系群（8）が認められる．左右の 弧状線系群（8），と中腹部下方領域の弧状線系群（7） に囲まれた領域，すなわち将来の恥丘部は，不整裂線団

(9) に充たされている.

b . 皮下脂肪層の状況

左右の鼠径部では，中型の棈円形を主体とした脂肪顆 粒からなり，顆粒はその長径を一定方向に向けて排列 し，上前腸骨棘部より恥骨結節外側部一向い，下方はほ ほ斜走であるが漸次上内方に向って突出度を增している (H). 恥骨部下方領域，すなわち将来の恥丘部では, 極 めて小型の円形顆粒からなり，方向性を示さない（I）.

c . 下腹部の皮膚分裂線と皮下脂肪層との比較

左右の鼠径部では弧状線系群（8）がみられ，乙の走 向とこれに対応する脂肪層（H）の脂肪顆粒の排列方向 とは一致する，恥骨部下方領域すなわち将来の恥丘部で は，不整裂線団（9）が認められるが，乙れに対応する 脂肪層（I）の脂肪顆粒は極めて小型の円形よりなり方 向性を示さない。

例2. 胎児 8 加月（早）

a. 分裂線の状況

左右の鼠径部では上前腸骨栜部より恥骨結節外側部に 向い下方はほぼ斜走であるが漸次，上内方に向って突出 度を增して行く弧状線系群（8）が認められる．左右の 弧状線系群（8）と中腹部下方領域の弧状線系群（7） に囲まれた領域，すなわち将来の恥丘部は，不整裂線団 （9）に充たされている. 
b . 皮下脂肪層の状況

左右の鼠径部では, 中型の棈円形を主体とした脂肪顆 粒からなり，顆粒はその長径を一定方向に 向けて排列 し，上前腸骨棘部より恥骨結節外側部へ向って並んでい る $(\mathrm{H})$ ）恥骨部下方領 域すなわち，将来の恥 丘部で は，極めて小型の円形顆粒からなり方向性を示さない ( I ).

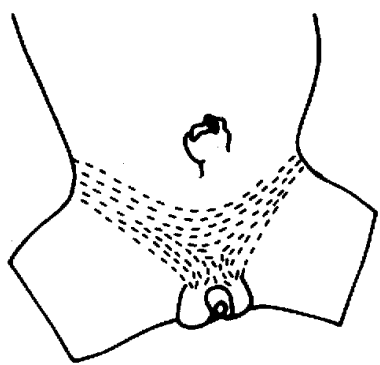

写 生 図

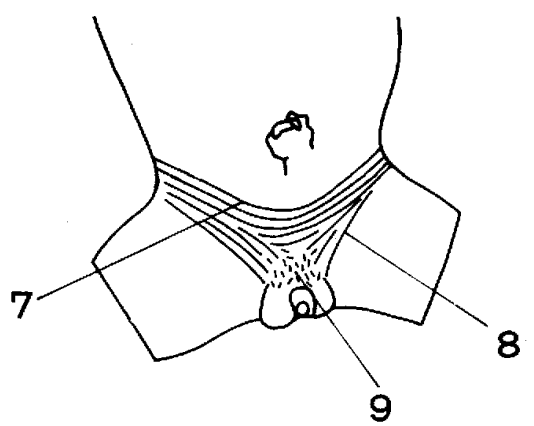

模 式図

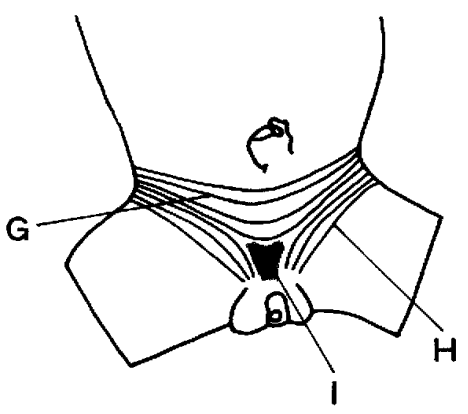

脂肪層の走行

下腹部 例 1 胎 坚 6 汃月

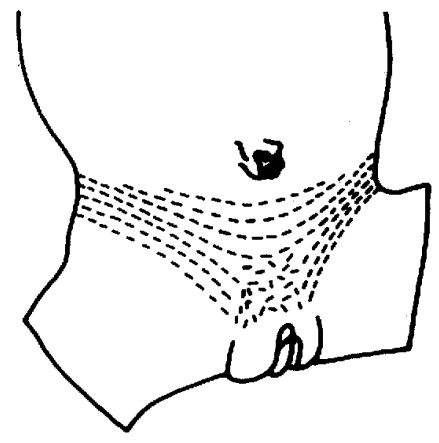

写 生 図

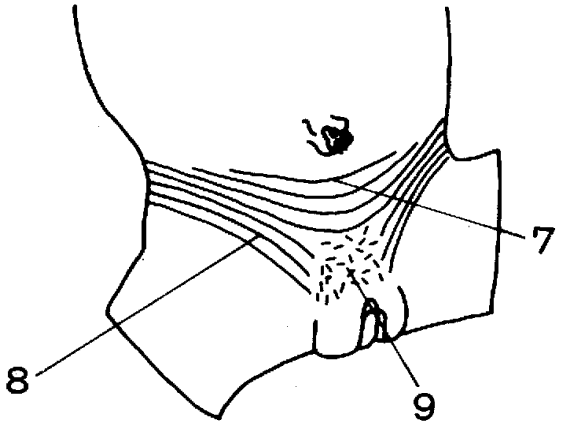

模 式 図

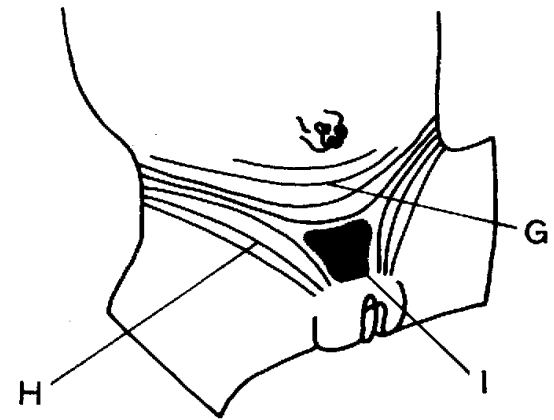

脂肪層の走行

下腹部 例 2 胎 児 8 か月

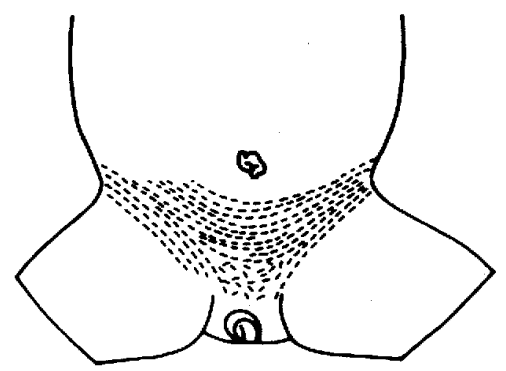

写生 図

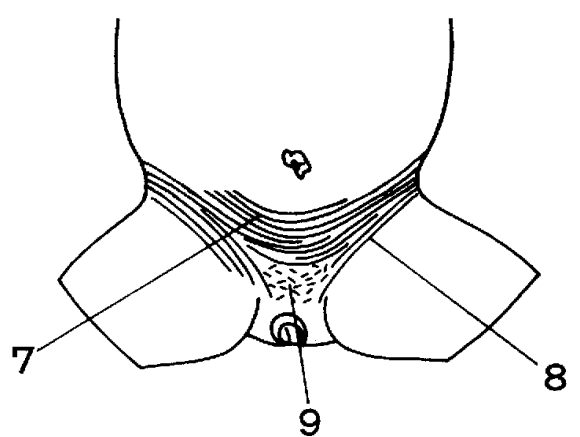

模 式図

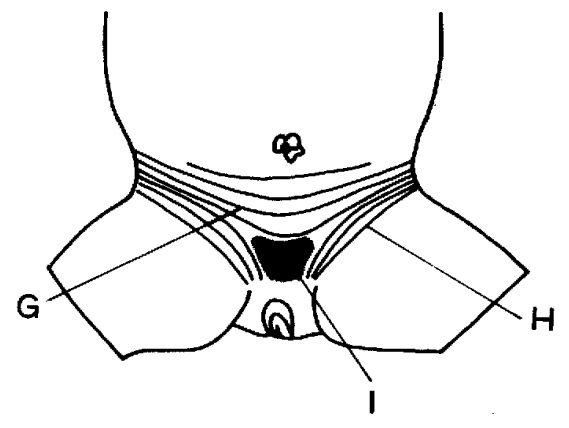

脂肪層の走行

下腹部例 3 胎 児 10 か月 
例3. 胎览10か月（古）

a . 分裂線の状況

左右の鼠径部では上前腸骨棘部より恥骨結節外側部に 向い下方はほぼ斜走であるが漸次，上内方に向って突出 度を增して行く弧状線系群（8）が認められる. 左右の 弧状線系群（8）と中腹部下方領域の弧状線系群（7） に囲まれた領域，すなわち将来の恥丘部は，不整裂線団

（9）に充たされている.

b . 皮下脂肪層の状況

左右の鼠径部では，やや大型の楕円形を主体とした脂 肪顆粒からなり，顆粒はその長径を一定方向に向けて排 列し，上前腸骨棘部より坹骨結節外側部へ向って並んで いる $(\mathrm{H})$ ，聒骨部下方領域すなわち，将来の恥丘部では， 極めて小型の円形顆粒からなり方向性を示さない（I）.

c. 下腹部の皮膚分裂線と皮下脂肪首との比較

左右の鼠径部では弧状線系群（8）がみられ，乙の走 向と乙れに対応する脂肪層 $(\mathbf{H})$ の脂肪顆粒の排列方向 とは一致する. 䎵骨部下方領域, すなわち, 将来の恥丘 部では，不整裂線団（9）が喼められるが，乙れに対応 する脂肪層（I） の脂肪顆粒は，極めて小型の円形より なり方向性を示さない。

\section{下腹部小括}

例 1 , 例 2 , 例 3 ともに下腹部では, 左右の鼠径部で は上前腸骨棘部より恥骨結節外側部へ向い，下方はほぽ 斜走であるが漸次，上内方に向って突出度を増して行く 弧状線系群（8）が認められ，乙れに対応する部の脂肪 層（H）は棈円形を主体とした脂肪顆粒よりなり，その 長径が一定した方向を示すため，顆粒の排列方向は明暸 であり脂肪層の走行と分裂線の線系の走向とは，よく一 致している. 中腹部下方領域の弧状線系群 (7) と左右 の弧状線系群（8）に囲まれる領域は不整裂線団（9） に充たされるが，乙れに対応する部の脂肪層（I）は極 めて小型の円形顆粒からなり, 方向性を示さない.

\section{D. 背 部}

背部における皮虚分裂線および皮下脂肪層の状況は， 図4に示すごとくである.

1. 胎児 6 加月

a . 分裂線の状沅

後頸部では横走線系群（1）が認められ，左右の肩甲 上部扔よび肩甲部上方領域では, 左右の局峰部より同側 の腋䆚部一问い内方に凸をなす弧状線系群 (2) が認め られる. 左右の肩甲部下方領域, 肩甲下部, 肩甲間部お よび外側胸部では 内上方より外下方に 向う斜 走線系群
（3）が認められる. 春柱部の第 4 〜胸椎部では 2 3 条の軽く傾斜する斜走線系（4）が認められる．横走 線系群 (1), 弧状線系群 (2), 斜走線系群 (3), 斜 走線系（4）に囲まれた領域では不整裂線団（5）に充 たされている。また腰部および外側部では横走線系群

(6) が認められ, 斜走線系 (4), 斜走線系群 (3), 横走線系群（6）に囲まれた領域は不整裂線団（7）に 充たされている.

\section{b . 皮下脂肪層の状況}

後頸部では中型のやや円形に近い楕円形を主体とした 脂肪顆粒からなり，顆粒はその長径を一定方向に向けて 排列し，頸部をとり巻くように並んでいる（A）。左右 の肩甲上部扔よび肩甲部上方領域では小型のやや円形に 近い棈円形を主体とした脂肪顆粒からなり，顆粒はその 長径を一定方向に向けて排列し，左右の肩峰部と同側の 腋筒部を結び，内方に凸をなすように並んでいる（B）。 左右の肩甲部下方領域，肩甲下部，肩甲間部および外側 胸部では中型の桂円形を主体とした脂肪顆粒よりなり， 顆粒はその長径を一定方向に向けて排列し, 内上方より 外下方に向い外側胸部をとり巻くように排列している

(C). 春柱部では小型の円形を主体とした脂肪顆粒か らなり，顆粒は円形であるためにその方向性はみられな い（D）。腰部および外側部ではやや大型の棈円形を主 体とした脂肪顆粒よりなり，顆粒はその長径を一定方向 に向けて排列し，腰部於よび外側部をとり巻くように並 んでいる (E).

\section{c．背部の皮膚分裂線と皮下脂肪首との比較}

後頸部では，横走線系群（1）が認められ，乙の線系 の走向とこれに対応する部の脂肪層（A）の肪脂顆粒の 排列方向とは一致する．左右の肩甲上部および肩甲部上 方領域では, 弧状線系群（2）が認められ，乙の線系の 走向とこれに対応する部の脂肪層（B）の脂肪顆粒の排 列方向とは一致する．左右の肩甲部下方領域，肩甲下部 ，局甲間部および外側胸部では斜走線系群 (3) が認め られ，乙の線系の走向とてれに対応する脂肪層（C）の 脂肪顆粒の排列方向とは一致する. 春柱部では不整裂線 団 (5)，斜走線系（4）および不整裂線団（7)が認め られるが，乙れに対応する脂肪首（D）の脂肪顆粒は方 向性が認められない, 左右の腰部および外側部では, 横 走線系群（6）方認められ，乙の線系の走向とこれに対 応する部の脂肪層 $(\mathrm{E})$ の脂肪顆粒の排列方向とは一致 する・

例2. 胎児 8 汃月 (우)

a . 分裂線の状況 
後頸部では 横走線系群（1），左右の肩甲上部および 肩甲部上方領域では 弧状線系群（2），肩甲間部および 外側胸部では 斜走線系群 ( 3 ), 春柱部の第 $4 \sim 7$ 胸椎 部では斜走線系（4）が認められる．以上の各線系群に 囲まれた領域には不整裂線団（5）が認められる。また 腰部, 脊柱部下方領域および外側部では横走線系群（6)
が認められ，斜走線系 (4), 斜走線系群 (3), 横走線 系群（6）に囲まれた領域では不整裂線団（7）に允た されている.

\section{b ． 皮下脂肪層の状況}

後頸部では 頸部をとり巻くように並んでいる脂肪圈 （A），左右の肩甲上部および肩甲部上方領域では，脂

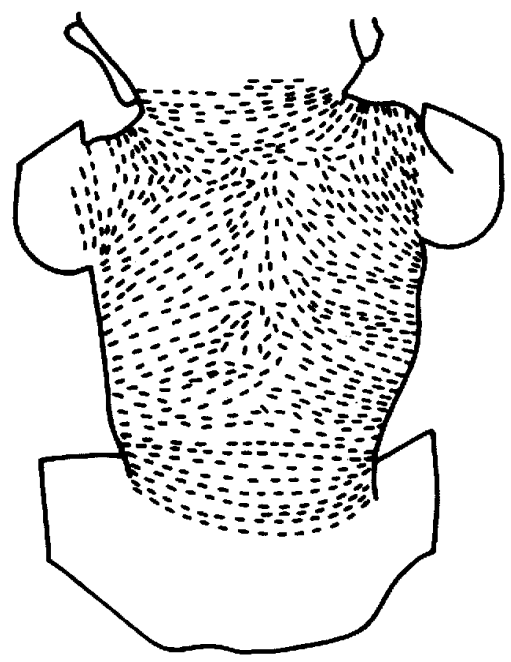

写生図

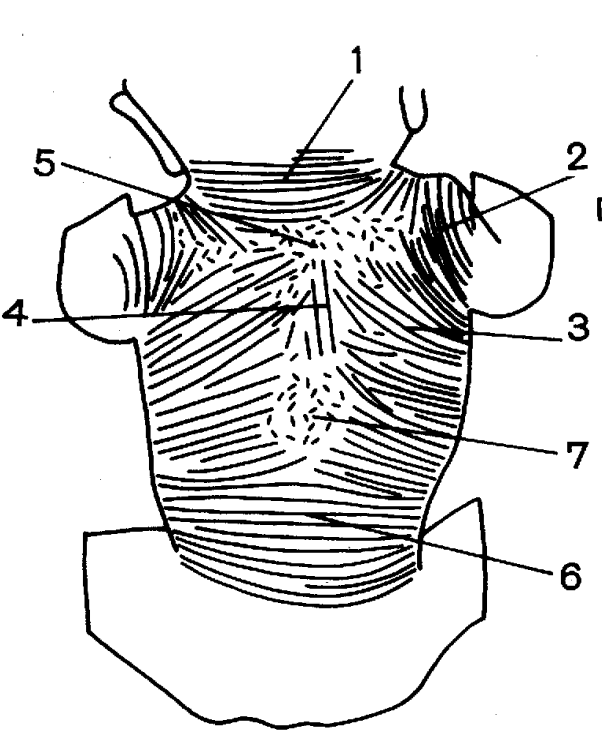

模 式 図

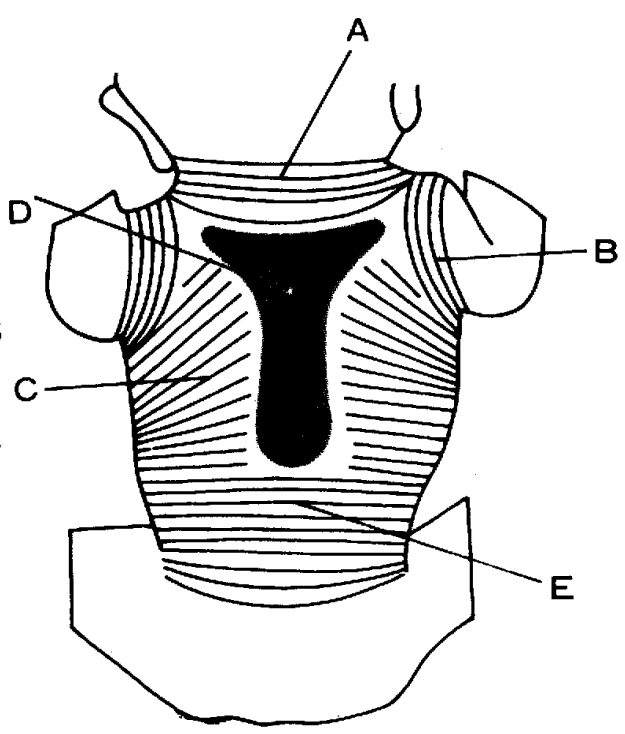

脂肪凲の走行

背 部 例 1 胎坚 6 か月

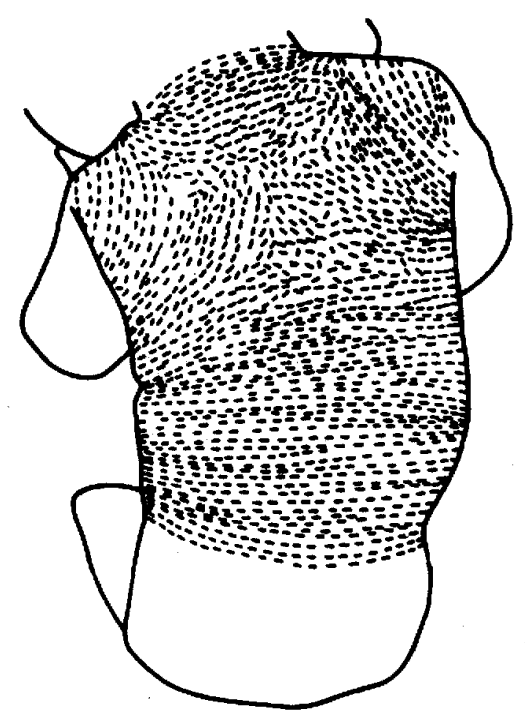

写 生 図

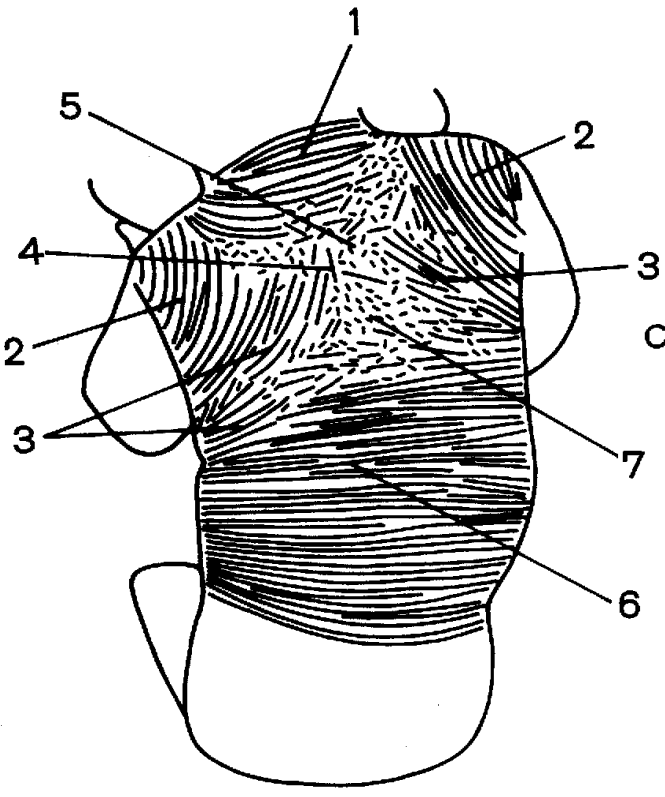

模 式 図

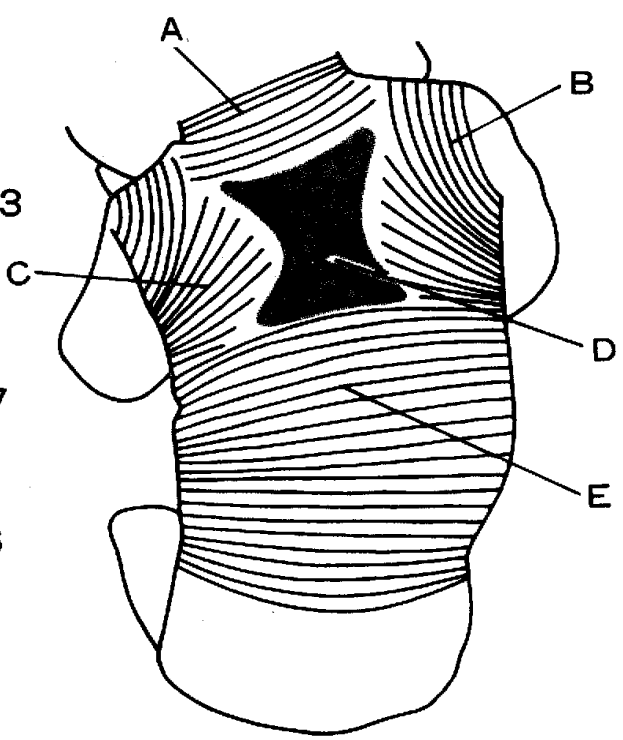

脂肪㬝の走行

背 部 例 2 胎坚 8 加月 
肪層（B），左右の肩甲部下方領域，肩甲間部および外 側胸部では，脂肪層 (C)，春柱部上方領域では，小型 円形の脂肪顆粒からなる脂肪層 (D), 腰部, 脊椎部下方 領域および外側部では脂肪層（E）などが認められる.

c. 背部の皮膚分裂線と皮下脂肪層との比較

後頸部では, 横走線系群（1）がみられるが，乙の線 系の走向と乙れに対応する部の脂肪層（A）の脂肪顆粒 の排列方向とは一致する．左右の肩甲上部および肩甲部 上方領域では, 弧状線系群（2）が認められ，乙の線系 の走向とてれに対応する部の脂肪層（B）の脂肪顆粒の 排列方向とは一致する，左右の肩甲部下方領域，局甲間 部および外側胸部では斜走線系群（3）が認められ，乙 の線系の走向とこれに対応する脂肪風 (C) の脂肪顆粒 の排列方向とは一致する，脊柱部上方領域では不整裂線 団 (5)，斜走線系（4）抢よび不整裂線団 $(7)$ ，が認 められるが，乙れに対応する脂肪層（D）の脂肪顆粓は 方向性が認められない，左右の腰部，泰柱部下方領域扔 よび外側部では，横走線系群（6）が認められ，乙の線 系の走向と乙れに詨応する部の脂肪層（E）の脂肪顆粒 の排列方向とは一致する。

例3. 胎児10汃月（古）

a . 分裂線の状沅

後頸部では 横走線系群 (1), 左右の肩甲上部および
痟甲部上方領域では 弧状線系群（2），肩甲間部および 外側胸部では 斜走線系群 (3)，脊柱部の第 $4 \sim 7$ 胸椎 部では斜走線系（4）が認められる. 以上の各線系群に 囲まれた領域には不整裂線団（5）が䜑められる。また 腰部, 春柱部下方領 域および 外 側 部では 横走 線系群

（6）が認められ, 斜走線系 (4), 斜走線系群 (3), 横走線系群（6）に囲まれた領域は不整裂線団（7）に 充たされている。

\section{b ．疮下脂肪層の状況}

後頸部では 頸部をとり巻くように並んでいる脂肪層 (A)，左右の肩甲上部执よび 肩甲部上方領域では，脂 肪層（B），左右の肩甲部下方領域，肩甲間部おうび外 側胸部では，脂肪首 $(\mathrm{C})$ ， 脊柱部上方領域では，小型 円形の脂肪顆粒からなる脂肪層 (D), 腰部, 脊柱部下 方領域および外側部では脂肪層（E）などが認められ る。

\section{c．背部の皮膚分裂線と皮下脂肪層との比較}

後頸部では，横走線系群（1）がみられるが，ての線 系の走向と乙れに刘応する部の脂肪層（A）の脂肪顆粒 の排列方向とは一致する．左右の肩甲上部および肩甲部 上方領域では弧状線系群（2）が認められ，乙の線系の 走向と乙れに対応する部の脂肪層（B）の脂肪顆粒の排 列方向とは一致する．左右の肩甲部下方領域，肩甲間部

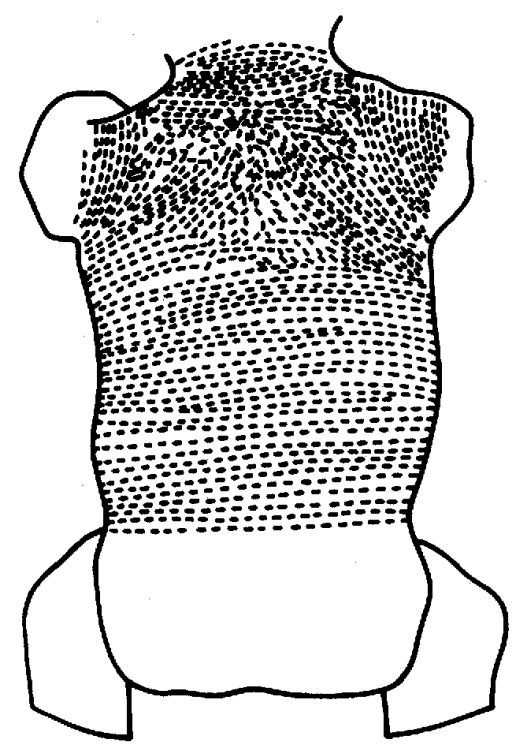

写 生 図

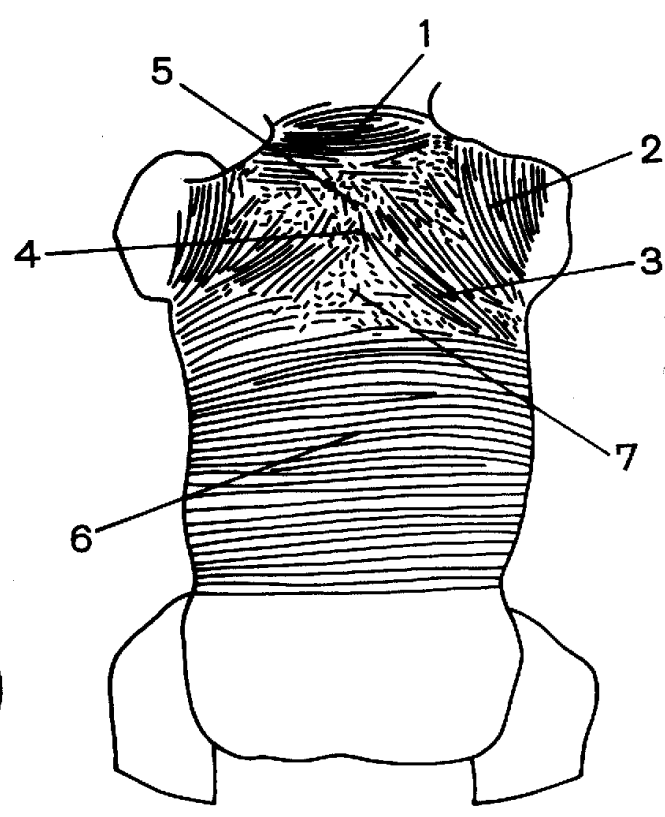

模 式 図

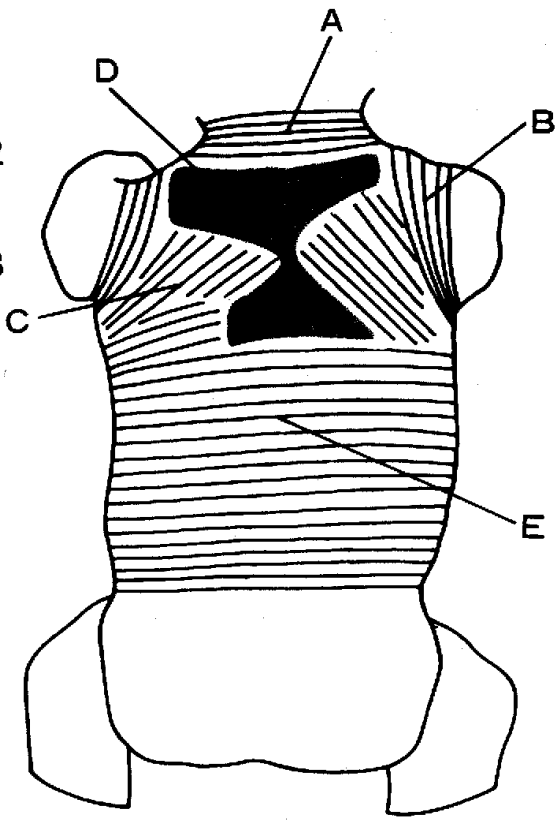

脂肪層の走行

背部例 3 胎巟 10 力月 
および外側胸部の斜走線系群（3）の線系の走向とこれ に対応する脂肪層 (C) の脂肪顆粒の排列方向とは一致 する。脊柱部上方領域では不整裂線団 ( 5 )，斜走線系

（4）および不整裂線団（7）が認められるが，乙れに 封応する脂肪層（D）の脂肪顆粒は方向性が認められな い. 左右の腰部抢よび外側部脊柱部下方領域では, 横走 線系群（6）が認められ，乙の線系の走向とこれに対応 する部の脂肪層 $(\mathrm{E})$ の脂肪顆粒の排列方向とは一致す る。

\section{背部小括}

後頸部の横走線系群 (1)，左右の肩甲部および肩甲 部上方領域の弧状線系群 (2), 肩甲間部 および外側胸 部の斜走線系群 (3)，腰部および 外側部の領域には， 横走線系群 (6) が認められ, 以上の独立的な各線系群 に対応する部の皮下脂肪層（A)，(B)，(C)，(E) は それぞれ異なった大きさの棈円形をした脂肪顆粒が排列 しており, 各線系群の分裂線の走向と一致している. 斜 走線系（4）に対応する部の皮下脂肪層抢よび横走線系 群 (1), 弧状線系群 (2), 斜走線系群 (3), 斜走線 系 (4)，横走線系群（6）に囲まれる部の不整裂線団 （5），（7）に対応する部の皮下脂肪層（D）は，小型 円形の脂肪顆粒が集まっており，その方向性を珰め得な い。ただし不整裂線団（7）打よびてれに対応する部の 皮下脂肪層（D）の範囲は，例 1 では背柱部の下方領域 まで見られるのに対し，例 2 , 例 3 の 2 例では，下方領 域は横走線系化し，春柱部の上方領域に 狭められてい る.

\section{E. 殿 部}

殿部における皮膚分裂線抢よび皮下脂肪層の状況は図 5 に示すでとくである.

例1. 胎児 6 分月（早）

\section{a . 分裂線の状沅}

腰部おるび外側部では横走線系群（6）が認められ， 仙骨部抽よび腰部, 脊柱部下方領域では限局性の不整裂 線団（8）が認められ，乙の部の下方では仙骨部より下 方の肛門部に向う縦走線系（9）が認められ, 該部の両 外側部で左右の腸骨棱最上部付近より同側の会陰部に向 い，内側上方に凸をなす弧状線系 $(10)$ ，短い弧状線系 （11）および大腿側に凸をなす弧状線系（12）が線系群 をなして認められる．肚門周縁部には不整裂線団（13） が認められる，なお，縦走線系（9）, 弧状線系（10）, (11)，（12）などの間には 不整裂線（14）が数個認めら れる。 b · 皮下脂肪層の状沅

腰部および外側部では中型の棈円形を主体とした脂肪 顆粒からなり顆粒は，その長径を一定方向に向けて排列 し腹部をとり巻くように並んでいる（E）。その下方領 域で，仙骨部に近接する部では，小型の円形を主体とし た脂肪顆粒からなり，顆粒は円形であるためにその方向 性はみられない（F）。仙骨部では小型の円形を主体と した脂肪顆粒からなり，顆粒は円形であるがりえにその 方向性はみられない（G）。仙骨部より下方の肛門部に 向う部ではやや小型の楕円形を主体とした脂肪顆粒から なり，顆粒は，その長径を一定方向に排列し，尾骨にそ うょうに並んでいる（H）。乙の部の両外側部では左右 の腸骨棱最上部付近より同側の会陰部に向う部は, やゃ 小型の棈円形を主体とした脂肪顆粒からなり，顆粒はそ の長径を一定方向に排列し，内側上方にロをなすように 並んでいる（I）。またその下外方部は，やゃ小型の棈 円形を主体とした脂肪顆粒からなり．顆粒は，その長径 を一定方向に 排列し，大腿側に凸をなすように並ぶ

( $\mathbf{J})$ ．肛門周縁部の 脂肪顆粒は小型の円形を主体とし 円形のために方向性はみられない（K)。

c . 殿部の皮膚分裂線と皮下脂肪層との比較 腰部抢上び外側部では横走線系群（6）が認められ， とれに対応する部の上方領域の脂肪層（E）の脂肪顆粒 の排列方向と，乙の横走線系群（6）の走向とは一致す る. 仙骨部および腰部, 脊柱部の下方領域では不整裂線 団（8）が認められ，乙れに対応する部の脂肪層 $(\mathrm{G})$ は小型の円形の脂肪顆粒が集まっており，その方向性は みられない，仙骨部より下方の肛門部に向ら部では，緹 走線系群（9）が認められ，乙れに対応する部の脂肪層

（H）は楕円形を主体とした脂肪顆粒よりなり，乙の脂 肪顆粒の排列方向と分裂線の走向の向きとは一致する. この部の両外側部では, 弧状線系群 (10)，(11), および (12) が認められ，乙れに対応する部の脂肪層 (I )，(J) は棈円形を主体とした脂肪顆粒よりなり，乙の顆粒の排 列方向と分裂線の線系の走向の向きとは一致する．肚門 周縁部では，不整裂線団（13）が認められ，これに対応 する部の脂肪風（K）は小型の円形を主体とした脂肪顆 粒よりなり，その方向性は諗められない，な打不整裂線

（14）に対応する部の脂肪層は，棈円形の脂肪顆粒を主 体としているが小型の円形，および不定形の脂肪顆粒が 比較的多く䜑められ，その方向性はやや明確度を欠いで いる.

例2. 胎児 8 分月（早）

a. 分裂線の状況 


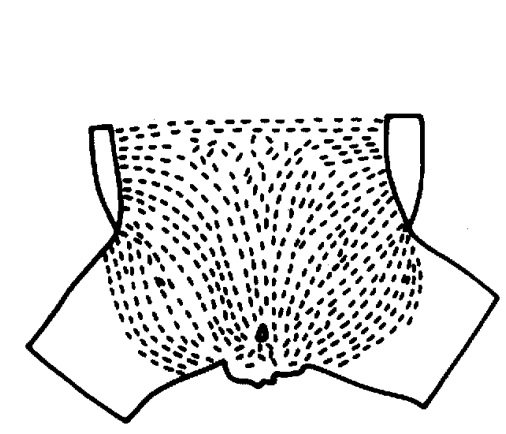

写 生 図

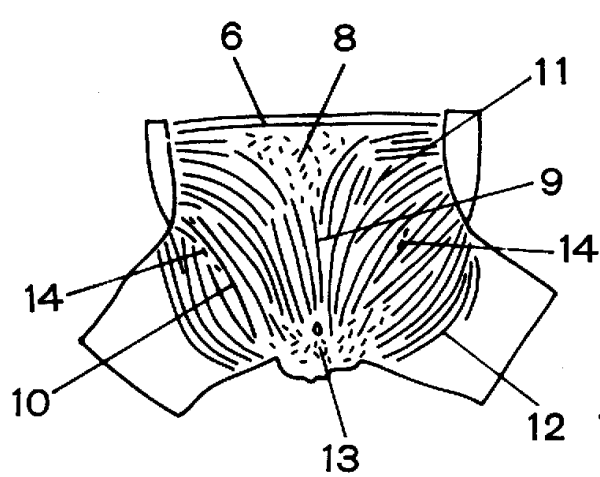

模 式 図

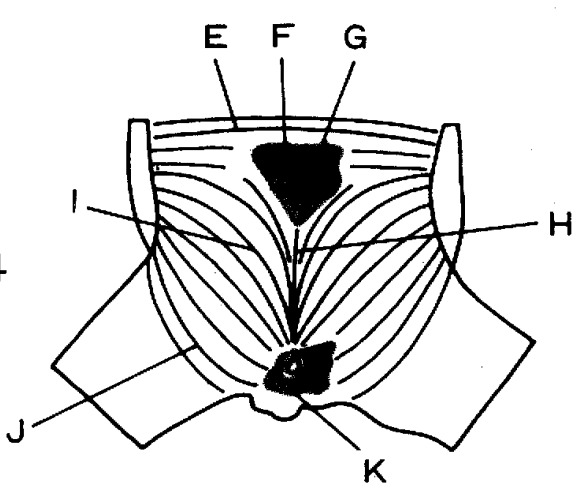

脂肪層の走行

殿 部 例 1 胎 览 6 加月

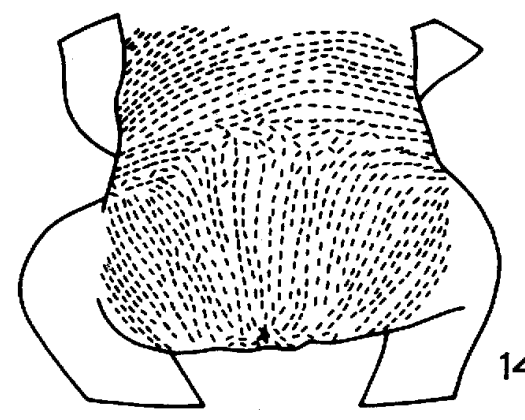

写 生 図

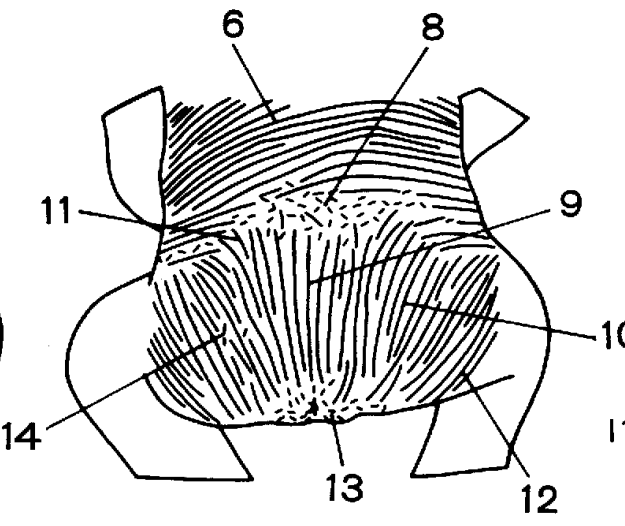

模 式 図

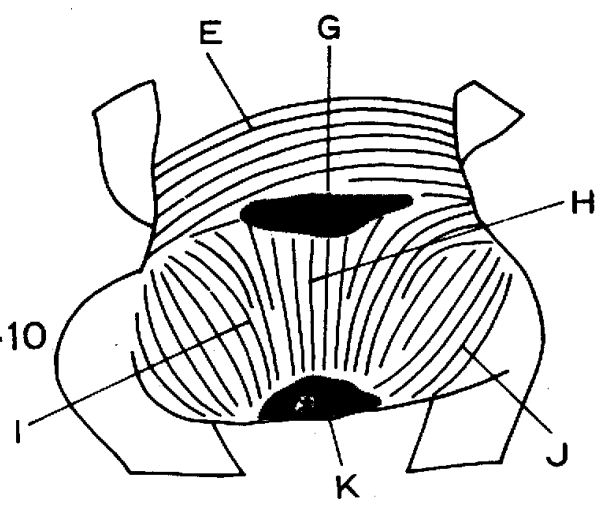

肪脂㬝の走行

殿 部 例 2 胎坚 8 加月

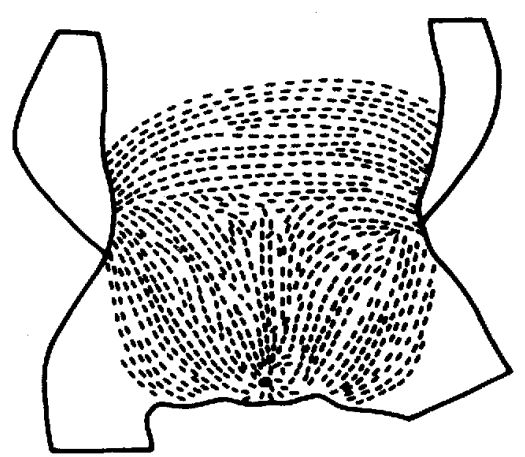

写 生 図

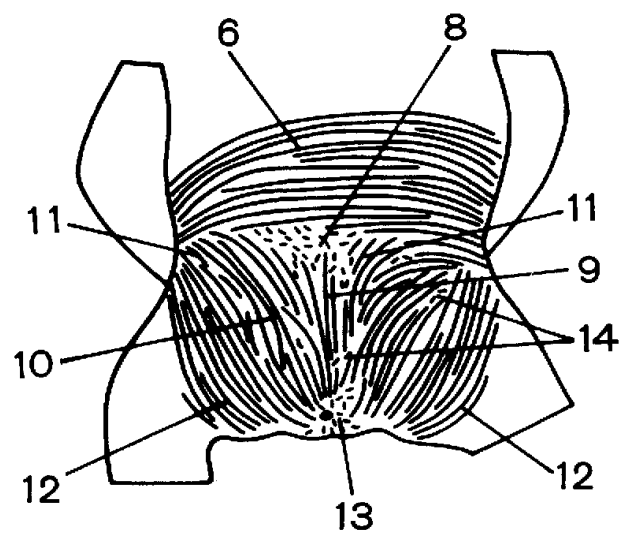

模 式 図

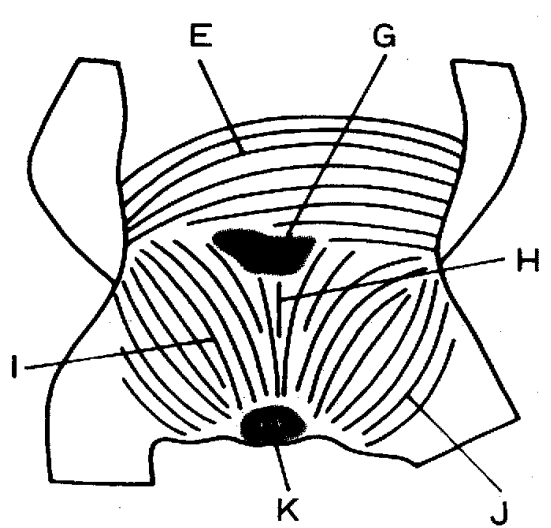

脂肪㬝の走行

殿 部 例 3 胎 巟 10 力月 
腰部およよ゙外側部では 横走線系群（6），仙骨部では 限局性の不整裂線団（8)，乙の部の下方では仙骨部より 下方の肛門部に向う縦走線系群（9）が広い範囲に認め られ，該部の両外側部で左右の腸骨稜最上部付近より同 側の会陰部に向い，内側上方に凸をなす弧状線系 $(\mathbf{1 0})$, 短い弧状線系（11）および 大腿側に凸をなす弧状線系 （12）が線系群をなして認められる，肚門周縁部には不 整裂線団（13）が認められる。なお，縦走線系 $(9)$, 弧状線系（10，（11）（12）などの間には数個の不整裂 線（14）が認められる。

b . 皮下脂肪層の状況

腰部および外側部では中型の楕円形を主体とした脂肪 顆粒からなり顆粒は，その長径を一定方向に向けて排列 し腹部をとり巻くように並んでいる（E）。仙骨部では 小型の円形を主体とした脂肪顆粒からなり，顆粒は円形 であるためにその方向性はみられない（G）。仙骨部よ り下方の肚門部に向う部では，やや小型の棈円形を主体 とした脂肪顆粒からなり，顆粒はその長径を一定方向に 排列し，尾骨にそうように並んでいる $(\mathbf{H})$. この部の 両外側部では左右の腸骨稜最上部付近より同側の会陰部 に向う部の脂肪層 (I ），またその 外下方 部の 脂肪層 (J)はいずれもやや小型の㮠円形を主体とした脂肪顆粒 よりなり，顆粒はその長径を一定方向に向けて排列して いる．肚門周縁部の脂肪層（K）は顆粒が小型の円形を 主体とし，円形のために方向性はみられない。

c . 殿部の皮虐分裂線と皮下脂肪層との比較

腰部および外側部に認められる横走線系群 $(6)$ ，乙れ に対応する部の脂肪層（E）の脂肪顆粒は中型の楕円形 のためその長径を一定方向に向けて排列し，乙の横走線 系群（6）の走向と一致する，仙骨部の不整裂線団 (8) に対応する部の脂肪層（G）は小型円形の脂肪顆粒が集 まっており，その方向性はみられない，仙骨部より下方 の肚門部に向う部にみられる縦走線系群 (9)，乙れに対 応する部の脂肪層（H）は楕円形を主体とした脂肪顆粒 からなり，この顆粒の排列方向と分裂線の走向の向きと は一致する.との部の両外側部では弧状線系群 $(10)$, (11)，（12）が喼められ，乙れに 対応する部の脂肪層 （I），（J），は楕円形を主体とした脂肪顆粒よりなり， この顆粒の排列方向と分裂線の線系の走向の向きとは- 致する，肚門周縁部で は，不整裂線団（13）が認めら れ，乙れに対応する部の脂肪層（K）は小型の円形を主 体とした肪脂顆粒よりなり，その方向性は認められな い．な抢不整裂線団（14）に対応する部の脂肪層は，棈 円形の脂肪顆粒を主体としているが小型の円形，および
不定形の脂肪顆粒が比較的多く認められ，その方向性は やや明確度を欠いでいる。

\section{例3．胎児10か月（早）}

a. 分裂線の状沅

腰部および外側部では 横走線系群 $(6)$ ，仙骨部では 限局性の不整裂線団 $(8))$ 仙骨部より下方の肛門部に向 う部では縦走線系 $(9)$ ，乙の部の両外側部では左右の腸 骨稜最上部付近より同側の会陰部に向う弧状線系 (10), 短い弧状線系(11) および大腿側に凸をなす弧状線系 (12) が線系群をなして認められる，肚門周縁部には不整裂線 団（13）が認められ，縦走線系（9）, 弧状線系（10）, (11)，(12）などの間には数個の不整裂線（14）が認めら れる.

b . 皮下脂肪凰の状沅

腰部および外側部では脂肪圈（E）が認められる。ま た仙骨部より下方の肛門部に向う部では脂肪圈 $(\mathbf{H}), 乙$ の部の両外側部では左右の腸骨稜最上部付近より同側の 会陰部に向う部の脂肪層（I），またその外下方部の脂肪 圈（J）など，小型および中型の棈円形を主体とした脂 肪顆粒からなり，顆粒はその長径を一定方向に向けて排 列している，仙骨部の脂肪層 $(\mathrm{G})$ ，䀴閘周縁部の脂肪層

（K）などは脂肪顆粒が小型の円形を主体とし，円形の ために方向性はみられない。

c . 殿部の皮膚分裂線と皮下脂肪層との比較

腰部および外側部に認められる横走線系群 $(6) ， 乙$ れに対応する部の脂肪風（E）の脂肪顆粒は中型の棈円 形のためその長径を一定方向に向けて排列し，分裂線の 線系の走向と一致する，仙骨部の不整裂線団（8）に対 応する部の脂肪層（G）は小型円形の脂肪顆粒が集って おり，その方向性はみられない，仙骨部より下方の肛門 部に向う部にみられる縦走線系群（9），乙れに対応す る部の脂肪首 $(\mathbf{H})$ は楕门形を主体とした脂肪顆粒から なり，乙の顆粒の排列方向と分裂線の走向の向きとは一 致する。乙の部の両外側部では弧状線系群 $(10),(11)$ ， (12) が認められ，乙れに対応する部の脂肪層（I），( J ) は楕円形を主体とした脂肪顆粒よりなり，ての顆粒の排 列方向と分裂線の 線系の 走向の向きとは一致する，肛 門周縁部では，不整裂線団（13）に充たされ，乙れに対 応する部の脂肪層（K）は小型の円形を主体とした脂肪 顆粒上りなり，その方向性は認められない，なお不整裂 楾（14）に対応する部の脂肪層は，棈円形の脂肪顆粒を 主体としているが小型の円形，および不定形の脂肪顆粒 が数多く認められ，その方向性はやや明確度を欠いでい る。 


\section{殿 部小括}

腰部および外側部の横走 線系群 $(6)$ ，仙骨部より下 方の肛門部に向う縦走線系群 (9), 左右の腸骨棱最上 部付近より同側の会陰部に向う弧状線系群 (10)，短い 弧状線系（11），および大腿側に山をなす弧状 線系群

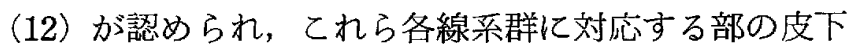
脂肪層（E)，(H)，（I），( J )，はそれぞれ異なった 大きさの楕円形をした脂肪顆粒が排列し，その長径が一 定した方向を示すため，顆粒の排列方向は明瞭であり脂 肪層の走行と各線系群の分裂線の走向とは，ょく一致し ている。.また腰部および外側部の横走線系群（6)，縦 走線系群 $(9)$ ，弧状線系群 (10) 亿囲まれる領域の不整 裂線団（8）および䀴閒周縁部の不整裂線団（13）に対 応する部の皮下脂肪首 $(\mathbf{G}) ，(\mathbf{K})$ は小型の円形の脂肪 顆粒が集まっておうり，その方向性を認め得ない，なお例 1 亿おいて，不整裂線団（8）の範囲が仙骨部のみなら ず腰部および春柱部の下方領域まで比較的広い範囲に見 られ，乙れに対応する部には脂肪風 $(F) ，(\mathrm{G})$ が見ら れたのに対し，例 2 ，例 3 の 2 例においては不整裂線団 （8）は仙骨部のみに限局され，乙れに対応する部には 脂肪層（G）が認められるのみで，例 1 において見られ た脂肪層（F）の領域は脂肪層（E）の領域に化してい る.

\section{総括および考察}

人胎児の 6 か月， 8 か月および $10 か$ 月の脂肪層発育の 顕著な体幹部について, 胸部, 上腹部および中腹部，下 腹部, 背部, 殿部の各 3 例計 15 例の分裂線の状況, 脂肪 層の状況およびそれらの走行関係を明らかにしてきた が，てれを総括すると次の如くである。

胸部では前頸部および左右側頸部の横走線系群 (1)， 前胸部の弧状線系群 (2)，左右の鎖骨部および 腋曧部 の弧状線系群（3）, 左右の側胸部および下肋部，上胃 部の横走線系群（4）などの線系が認められる。すなわ ち分裂線の独立的な各線系群に対応する部の皮下脂肪層

(A)，（B），(C)，(D) はそれぞれ異なった大きさの 楕円形をした脂肪顆粒が排列しており，その長径が一定 した方向を示すため顆粒の排列方向は明瞭であり脂肪首 の走行と各線系群の分裂線の走向とは, ょく一致してい る。また，前胸部の弧状線系群（2），左右の鑜骨部扢 よび腋窩部の弧状線系群（3），左右の 側胸部よび下肋 部, 上胃部の横走線系群（4）に囲まれる部，すなわち 将来乳岸を形成する部には，不整裂線団（5）が認めら れ，乙れに対応する部の脂肪層（E）は小型の円形の脂
肪顆粒が集っており，その方向性を認め得ない．

上腹部および中腹部では, 上腹部の横走線系群 ( 4 ), 中腹部下方領域でみる弧状線系群（7）などの線系が認 められ，乙れらの各線系群に対応する部の上腹部の皮下 脂肪層 (D)，下腹部の脂肪層（G）は，それぞれ異な った大きさの棈内形をした脂肪顆粒が排列しており，そ の長径が一定した方向を示すため, 顆粒の排列方向は明 暸であり脂肪層の走行と各線系群の分裂線の走向とは, よく一致している，臍の周囲には不整裂線団（6）が認 められ，乙れに対応する部の脂肪層（F）は中型の楕円 形の脂肪顆粒よりなり，臍をとり巻くようであり，臍の 上・下方に凸をなすように排列している。

下腹部では弧状線系群（8）が認められ，乙れに対応 する部の脂肪層（H）は楕円形を主体とした脂肪顆粒よ りなり，その長径が一定した方向を示すため，顆粒の排 列方向は明瞭であり脂肪層の走行と分線裂の線系の走向 とは, 上く一致している，中腹部下方領域の弧状線系群

（7）および上前腸骨棘部より䎵骨結節外側部へ向う弧 状線系群（8）に囲まれる領域は，不整裂線団（9）に 充たされるが，てれに対応する部の脂肪層（I）は極め て小型の円形顆粒からなり，方向性を示さない。

背部では, 後頸部の横走線系群 (1), 左右の肩峰部 より同側の腋窩部にみる 弧状線系群 (2), 局甲間部お よび外側胸部の斜走線系群 (3), 腰部抢よび外側部の 横走線系群（6）が認められ，乙れら独立的な各線系群 飞対応する部の皮下脂肪層（A)，(B)，(C)，(E) は それぞれ異なった大きさの楕円形をした脂肪顆粒が排列 しており，各線系群の分裂線の走向と一致している. 斜 走線系 (4) に対応する部の皮下脂肪層および後頸部の 横走線系群 (1), 左右の肩峰部より 同側の腋窩部にみ る弧状線系群 (2), 肩甲間部抢よび外側胸部の斜走線 系群 (3), 脊柱部 $の$ 第 $4 \sim 7$ 胸椎部 斜 走 線 系群 (4)，䁏部および外側部の横走線系群 (6) に囲まれ る部の不整裂線団（5)，（7）に対応する部の皮下脂肪 層（D）は，小型円形の脂肪顆粒が集まっており，その 方向性を認め得ない。

殿部では，腹部背面の横走線系群 (6)，仙骨部より 下方の肛門部に向う 縦走線系群 (9), 左右の腸骨棱最 上部付近上り同側の会陰部に向う弧状線系群 $(10)$, 短 い弧状線系(11)，および大腿側に凸をなす弧状線系 (12）が認められ，それぞれの各線系群に対応する部の 皮下脂肪層（E），(H)，（I），（J）はそれぞれ異なっ た大きさの楕円形をした脂肪顆粒が排列し，その長径が 一定した方向を示すため, 顆粒の排列方向は明瞭であり 
脂肪層の走行と各線系群の分裂線の走向とは，よく一致 している。 また腰部背面の横走線系群 (6), 仙骨部よ り下方の肚門部に向う縦走線系群 ( 9 ), 左右の腸骨稜 最上部付近より同側の会陰部に向う弧状線系群（10）に 囲まれる領域の不整裂線団（8）および肛門周縁部の不 整裂線団（13）に対応する部の皮下脂肪層 $(\mathrm{G}),(\mathrm{K})$ は小型の円形の脂肪顆粒が集まっており，その方向性を 認め得ない。

ところで分裂線の線系の走向と脂肪顆粒の排列方向と が一致しない部位としては，つぎのものがあげられる。

上腹部および中腹部では， 3 例ともに，臍の周囲でてれ をとり巻く囲繞線系化の傾向を示す不整裂線団（6）が 認められるが，乙れに対応する部の脂肪層（F）の脂肪 顆粒は，その長径が一定した方向を示すため顆粒の排列 方向は明膫であり，臍をとり巻き上・下方に凸をなすよ うに整然と排列している。背部では， 3 例ともに脊柱部 の第 $4 \sim 7$ 胸椎部门抏いて, 数条の僅加佰斜する斜走 線系（4）が認められるが，乙れ対応する部の脂肪層

（D）の脂肪顆粒は，小型円形でその方向性を認め得な い．以上のでとく細部にわたり観察すると，多少の差異 はあるにしても，全体的に観ると，各線系群に対応する 部の皮下脂肪層は, 棈円形を主体としてた脂肪顆䊉が排 列しており，その長径が一定した走行を示すため，顆粒 の排列方向は明暸であり脂肪層の走行と分裂線の走行と は一致している．また各不整裂線団に対応する部の皮下 脂肪層は, 円形抢よび不定形を主体とした脂肪顆粒より なり，その方向性を認め得ない，すなわち，乙れら不整 裂線団に対応する部の皮下脂肪風に小型の円形抢よび不 定形をした脂肪顆粒が集まっている事実は，中山が述べ ているように，不整裂線団は発育方向の衝突部であり， てれに対応する部の脂肪層が小型の円形あるいは不定形 の顆粒からなり方向性を示さないととは，分裂線におい ても脂肪層に扔いても共にそれが内的発青力の衝突部で あるてとを示している. 将来の乳房部扔よび恥丘部にお ける脂肪顆粒が小梨円形の顆粒であることは胎児期に脂 肪掑取が少ないてとと同時に外周より圧迫されて皮膚側 に乫出した状態であろうと思われる．思春期に至って該 部が急に膨隆する準備状態であることを容易に想像でき るものである。

\section{結 論}

人胎児を用い，皮膚分裂線の状沅と皮下脂肪層の状況 とを詳細に観察し，検討して，つぎのごとき結論を得た。

1. 皮膚分裂線の状況之皮下脂肪層の状沅とは, 胼部
で稍趣を異にするが全般的に非常に良く一致した相互関 係にあるてとを示している，すなわち分裂線の独立的な 各線系群に対応する部の皮下脂肪層はそれぞれ異なった 大きさの楕円形をした脂肪顆粒が排列しており，その長 径が一定した方向を示すため, 明瞭な皮下脂肪層の走行 を知ることができる，乙の走向は良く分裂線の線系の走 向と一致している.

2. $2 \sim 3$ の独立線系群に囲まれる領域は不整裂線団 に充たされるが，てれに対応する部の脂肪層は小円形の 脂肪顆粒が集まっておりその方向性を認め得ない。

3. 以上の事実は中山が分裂線について「線系は発育 方向の示現であり，不整裂線は発育方向の乱れである」 すなわち発育構築であるとする見解を明瞭に裹付ける一 面である.

稿を終るにあたり本研究に終始䅰篤なる御指導, 御鞭 撻ならびに御校閲の労を賜わった恩師中山種秋教授に深 甚なる敬意と感謝の意を捧げます．また村上守良先生， 六反田篤先生, 伊東励先生の親身なる御援助に対し深く 感謝の意を表します，あわせて，本研究に最後まで御協 力下った解剖学教室の皆様に厚く御礼申し上げます。

\section{引用 文 献}

1. Dupuytren (1836) : 引用, 坂口幸介 : 肖緻密質の 構築について, 医学研究 9:1-92, 1935.

2. Langer,K. (1861) : 引用, 坂口幸介: 骨緻密質の 構築について, 医学研究 9:1-92, 1935.

3. Burkard, O. (1913) : 引用, 大森忠雄: 卵矢膜 分裂線の比較解剖学的研究, 九州歯会誌 11 : $1-4,1957$.

4. 小木層 (1942) : 引用, 阿部薰: 胎児皮膚の分裂線 と毛流との関係に就て, 九州菌会誌 $13(1)$ : 23-42, 1959.

5. 友田好範：諸臓器（辠丸, 腎, 睥, 肝）表面に於け る結合 線維の配列について, 医学研究 19： 215-222, 1949.

6. 山本政明：旗頭諸軟骨，気管及び肺臓表面に於ける 罅隙線须つて, 医学研究 $20: 923-935$, 1950.

7. 連理安武: 筋膜の鎼腺線について, 医学研究 21 : 1088-1121， 1951.

8. 西尾三吾 (1951) ：引用, 橋本元明：口蓋粘膜並び に曾槽粘膜の罅線に関する研究, 金沢大学医学 部解剖学教室業績 第52冊 : 21-40, 1954. 


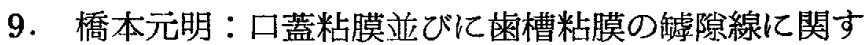
万研究，金沢大学医学部解剖学教室業績 52 ： 21-40, 1954.

10. 中山種秋：骨分裂線特に不整裂線の意義, 九州捆会 誌 11（1）：1-4，1957.

11. 土佐純生：哺乳動物眼球強膜の分裂線に関する比較 解剖学的研究, 熊本医学会誌 $30(7): 67-$ 81, 1956.

12. 大森忠雄: 畞款膜分裂線の比較解剖学的研究, 九州 菌会誌 11（3）：1-4，1957.

13. 阿部 董：犬眼球球琗膜の発育に伴う分裂線の変化 に就て，熊本医学会誌 33 (補 4) ：268-277 1959.

14. 鶴丸正博：犬の精巣鞘膜臓側板上に於ける分裂線の 年柃的変化について，九州菌会誌 $13(2)$ : 59-68, 1959.

15. 鶴丸正博：犬の卵巣霆上に現われる分裂線の年㱓的 変化について，九州荗会誌 $14(1) ： 217-$ $221,1960$.

16. 松隈荘一：犬の脾被 膜 分裂線の加粭的変化につい て, 九州雨会誌 14 (2) : 25-36, 1960.

17. 沖重豊美：犬胃漿膜分裂線の年路的観察，九州歯会 誌 14 (2) : 37-44, 1960 .

18. 中道正義：犬の舌粘膜分裂線の 加秢的変化につい て, 九州歯会誌 23（1）：1-8，1969.

19. 森進一郎：犬の舌粘膜に扔ける分裂線特に不整裂線 の機能的解析，九州曾会誌 $25(3) ： 265-$ $288,1971$.

20. 小川秀雄：犬の腎被膜（線維被膜深層）分裂線の加 龄的変化について，九州雾会誌 $30(3): 281$ $-309,1976$.

21. 村上彦四郎：犬の脳硬膜分裂線の加粭的変化につい て, 九州齒会誌 30 (4) : 532-561, 1976.

22. 福井（1936）：引用, 阿部董：胎児皮膚の分裂線上 毛流の関係䎲就いて，九州䒩会誌 $13(1)$ ： 23-42, 1959.

23. 阿部 董：胎览皮虐の 分裂線と毛流の 関係に 就い て，九州曾会誌 13 (1) : 23-42，1959.

24. Oder（1911）：引用，橋本京一：胎児軀幹皮下肪
脂の発生学的研究, 東京歯科大学解剖学教室業 績集 $6: 1-23,1958$.

25. Neuman (1922) ：引用，橋本京：一胎览島區幹皮 下脂肪の発生学的研究, 東京歯科大学解剖学教 室業績集 $6: 1-23,1958$.

26. Batkin（1915）：引用，橋本京一：胎児 軀幹皮下 脂肪の発生学的研究, 東京茵科大学解剖学教室 業續集 $6: 1-23,1958$.

27. Peisen (1921)：引用, 橋本京一：胎児軀幹皮下 脂肪の発生学的研究，東京菌科大学解剖学教室 業續集 $6: 1-23 ， 1958$.

28. Lasch (1927) : 引用, 橋本京一：胎児軀幹皮下脂 肪の発生学的研究, 東京菌科大学解剖学教室業 績集 $6: 1-23,1958$.

29. Baüer（1922）：引用, 橋本京一：胎児軀幹皮下脂 肪の発生学的研究, 東京歯科大学解剖学教室業 䋶集 $6: 1-23 ， 1958$.

30. Hille (1923) : 引用, 橋本京一：胎児軀幹皮下脂 肪の発生学的研究, 東京粜科大学解剖学教室業 績集 $6: 1-23,1958$.

31 徳永勝彦: 邦人胎児に於ける脂肪の肉眼的発生並び に分布に関する研究，第一篇鸓幹並びに四肢に 於ける筋間の脂肪, 長崎医学会雑誌 $31(7)$ : 486-526, 1956.

32. 最勝寺正安：邦人胎児に於ける皮下脂肪の肉眼的発 生並びに分布，長崎医学会誌雑誌 $33(6)$ ： 662-691, 1958.

33. 紫山一雄：胎児四肢皮下脂肪の発生学的研究, 口腔 解剖研究 (東京歯科大学解剖学教室業績集)

$17: 131-176,1960$.

34. 橋本京一：胎児軀幹皮下脂肪の発生学的研究, 東京 歯科大学解剖学教室業績集 $6: 1-23,1958$. 35. 浅井昇：身体各所の皮下脂肪厚度の年令的差異, 児 科雑誌 $389: 77 \sim 87,1932$.

36. 厚木学：日本人初生児の皮下脂肪分布に就いて，東 京医学会誌 47 （5）：165-198， 1933.

37. 厚木学：老年期に扔ける日本人の皮下脂肪分布に就 いて，東京医学会誌 $48 （ 6 ） ： 153-178$, 1934. 


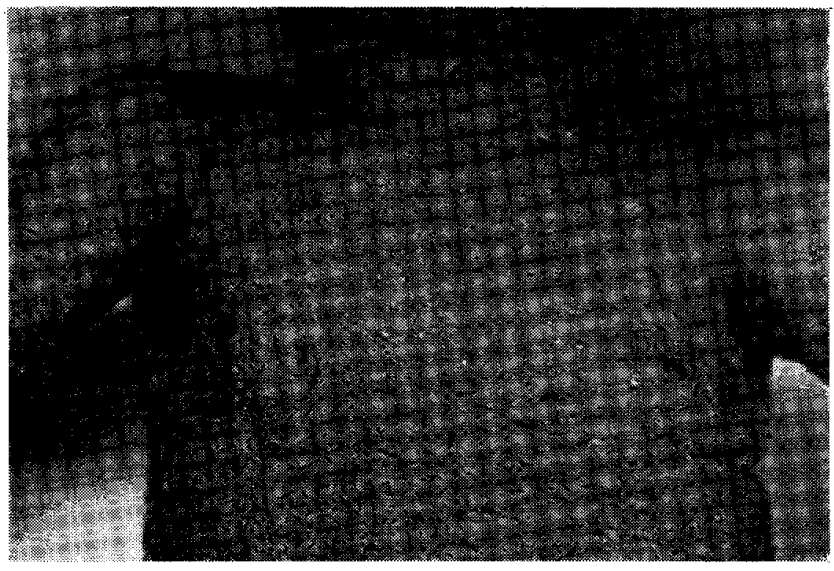

胸

部

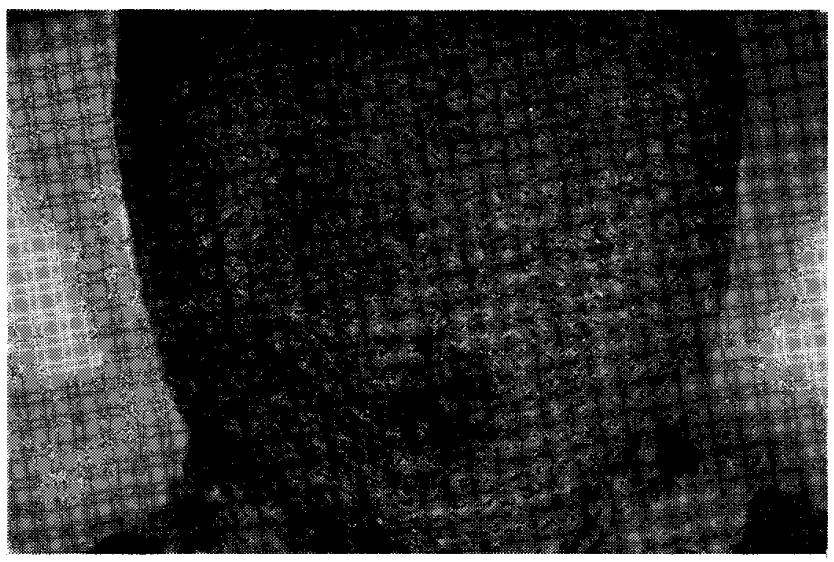

上腹部抢よび中腹部

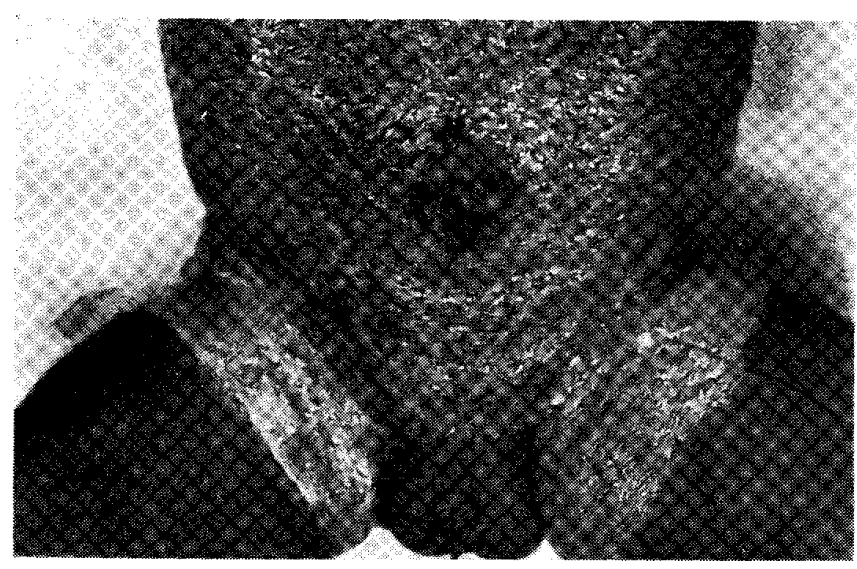

下腹部

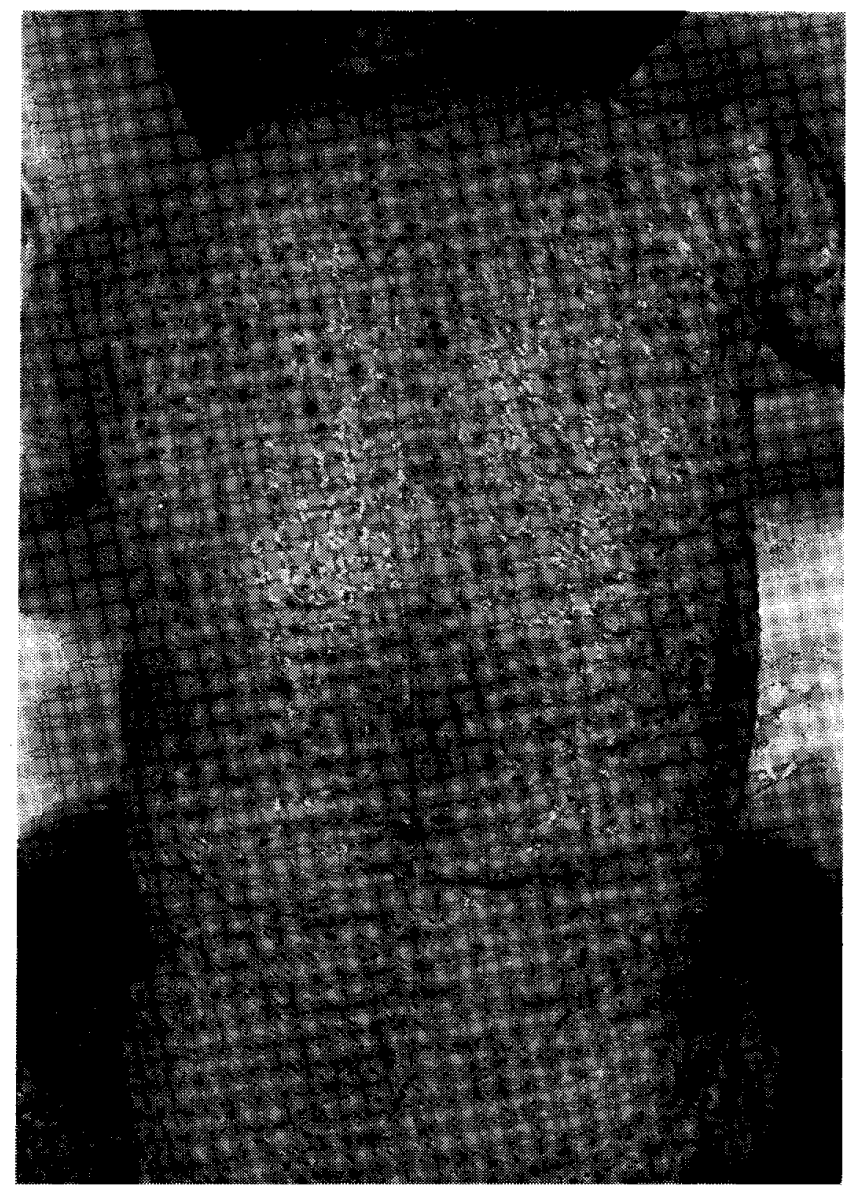

背

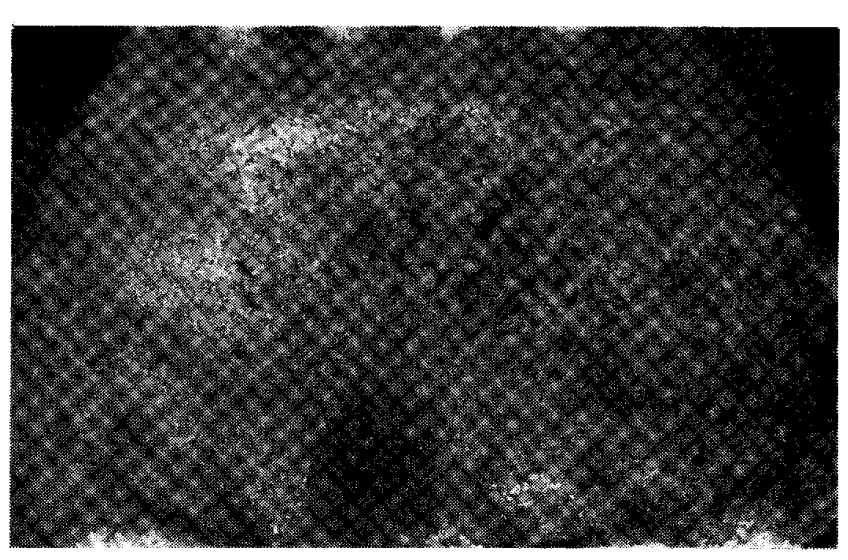

殿部 


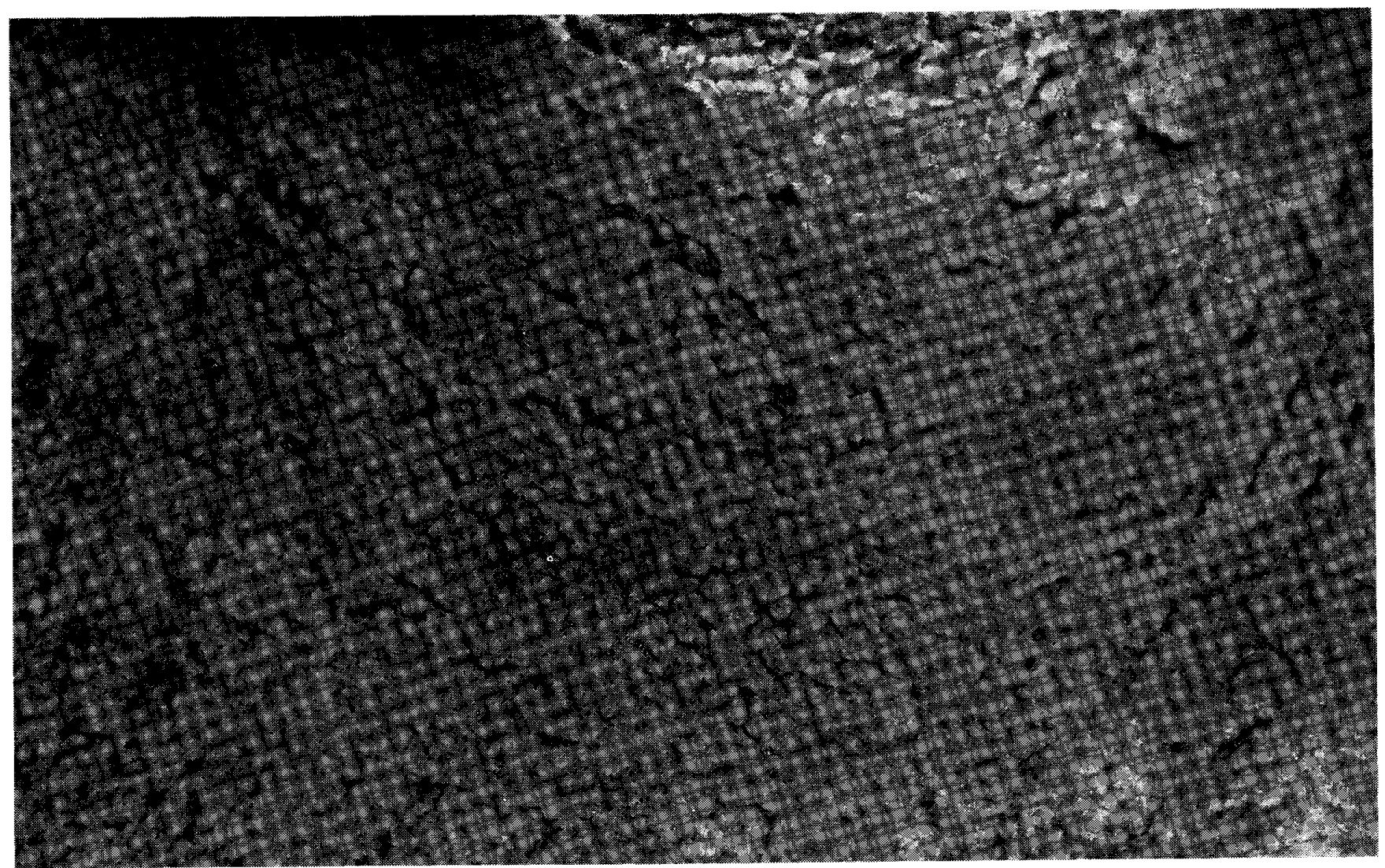

项・胸部抬大図

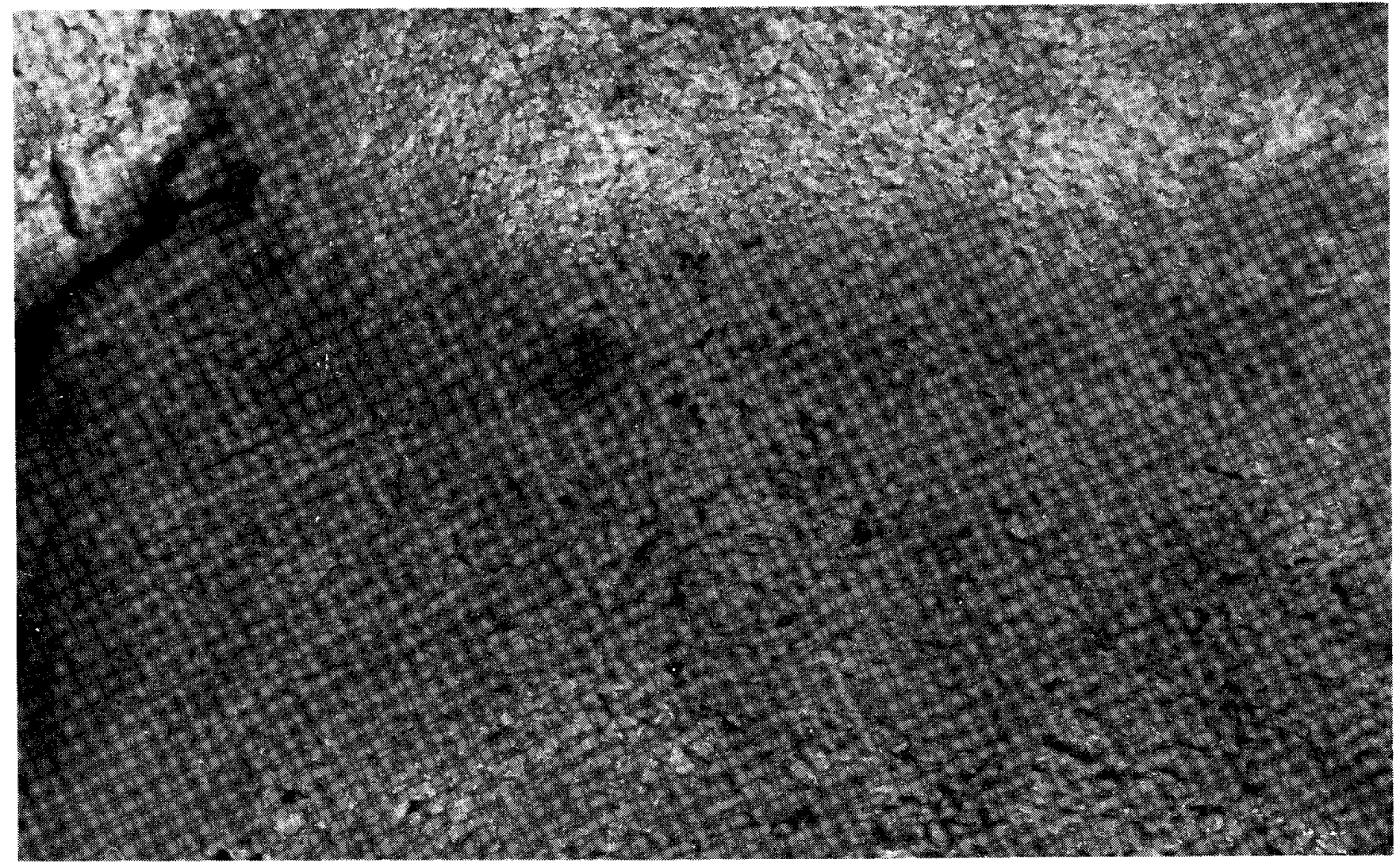

乳房部抬大四

等 2




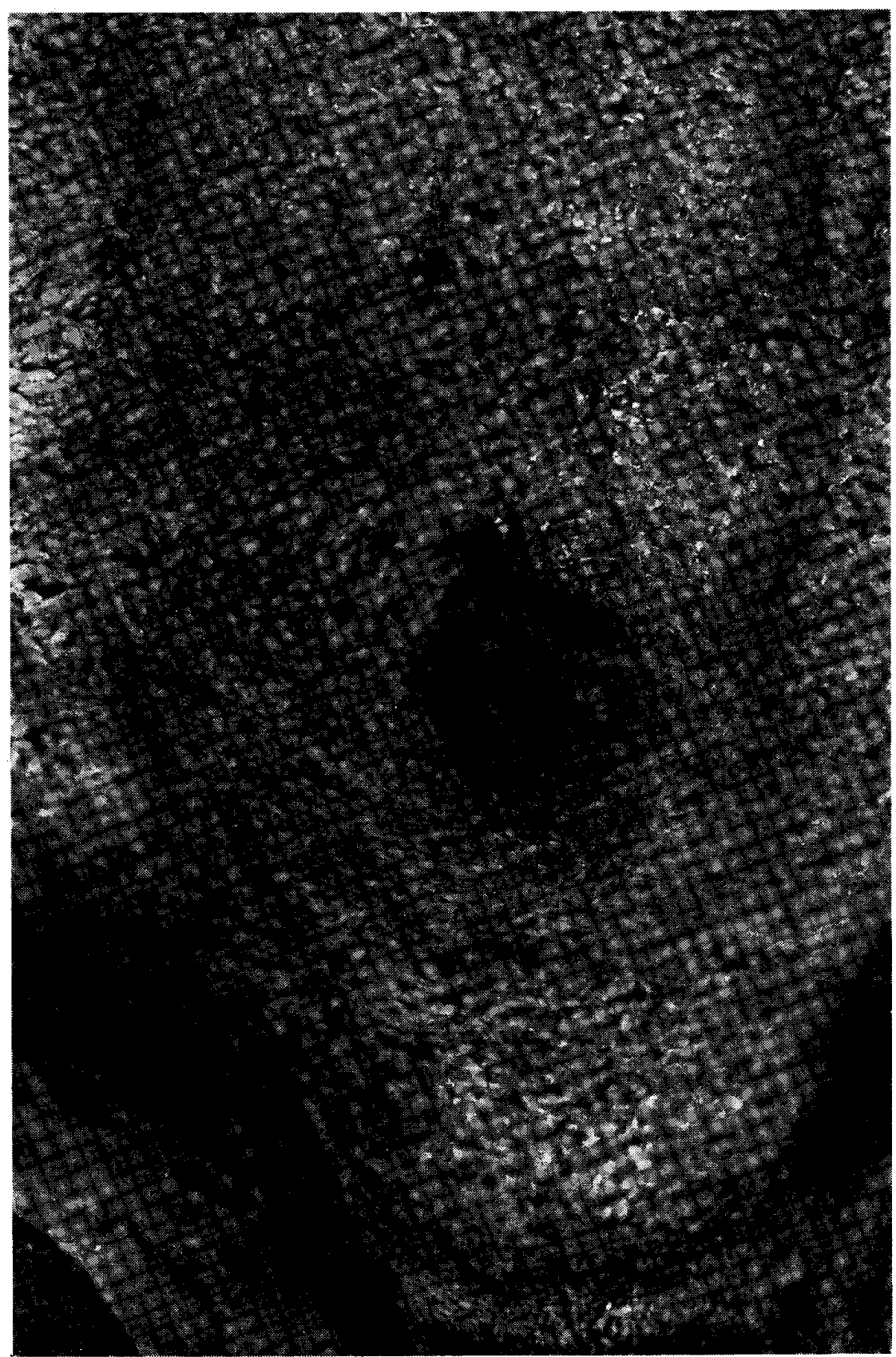

臍 - 恥骨部拡大図 
写 喜 4

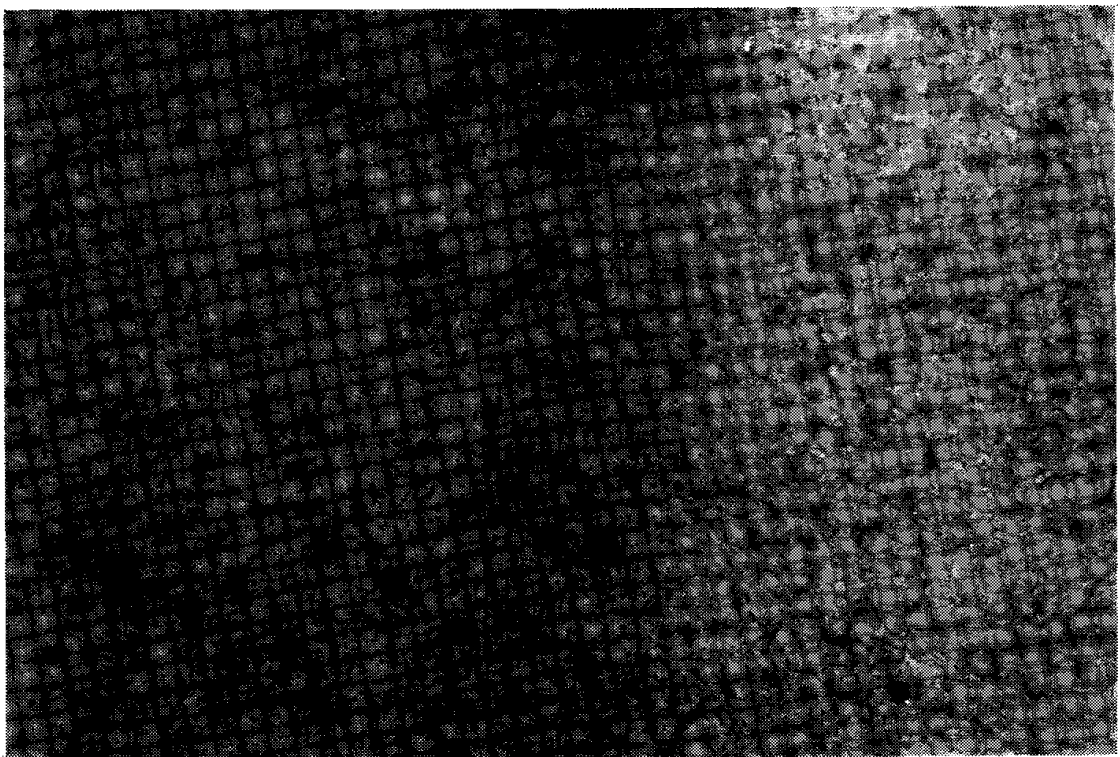

大

図
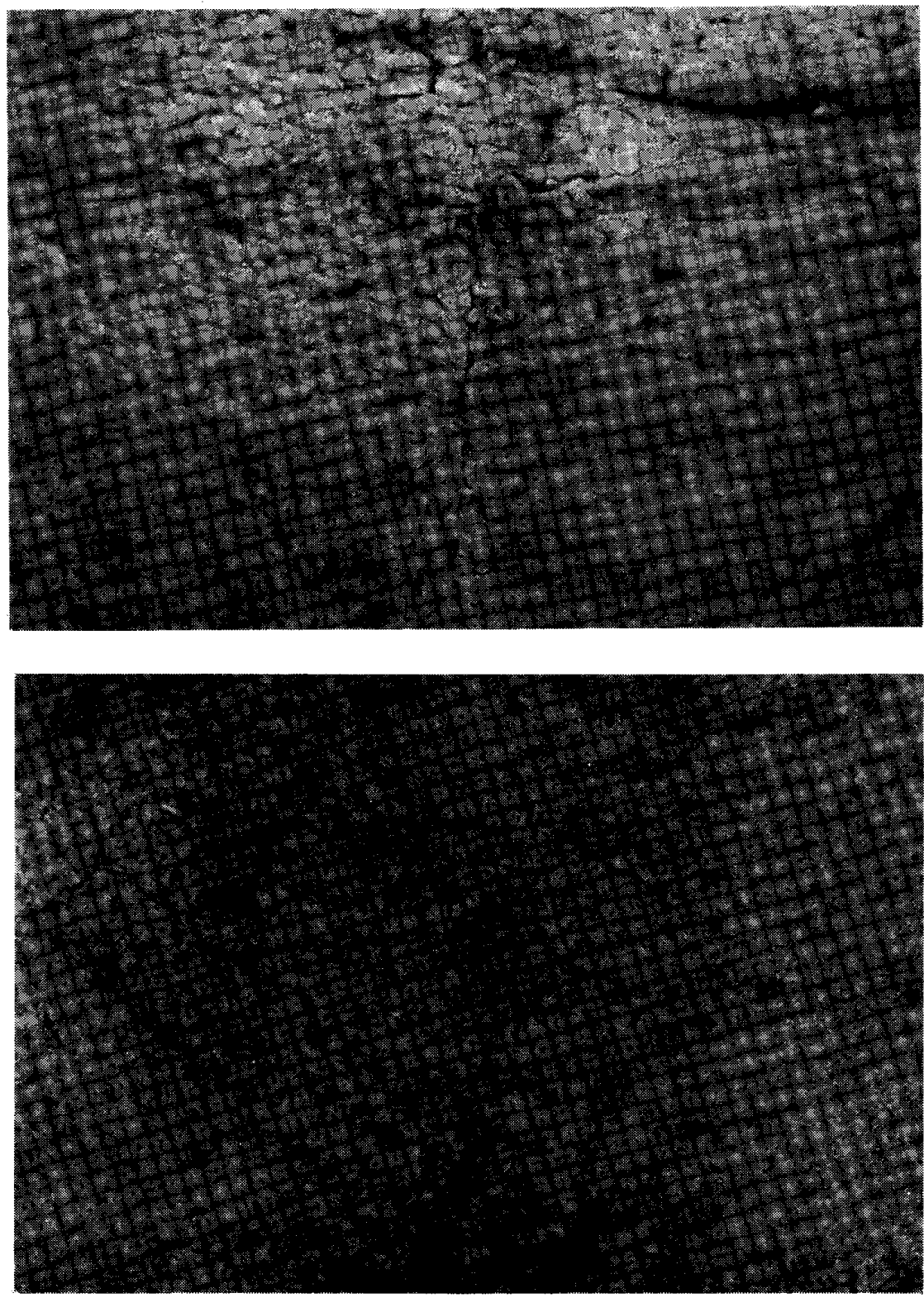